Journal of Educational

and Psychological Sciences

Volume (5), Issue (39): 30 Oct 2021

P: 72 - 95

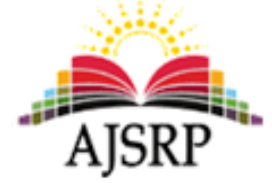

ISSN: 2522-3399
مجلة العلوم

التربوية والنفسية

المجلد (5)، العدد (39): 30 أكتوبر 2021 م

ص: 72 - 72 (n)

\title{
The relationship between science teachers' use of the flipped classroom strategy and their attitudes towards developing higher-order thinking skills among upper basic stage students in Hebron
}

\author{
Haneen Mahmoud Taha Bostanje \\ Directorate of Education South Hebron || Ministry of Education || Palestine
}

\begin{abstract}
The study aimed to identify the relationship between science teachers' use of the flipped classroom strategy and their attitudes towards developing higher-order thinking skills among students of the higher basic stage in the Hebron governorate. In order to achieve the goal of the study, the researcher followed the descriptive and analytical approach, as she/he conducted a questionnaire to measure the extent to which science teachers use the flipped classroom strategy, and she conducted another questionnaire to measure the attitudes of science teachers towards developing higher-order thinking skills among students of the higher basic stage. Then, the two questionnaire sheets are electronically applied to a random sample of science teachers in the Hebron governorate. The number of the sample is (136) teachers in all directorates of the Hebron governorate.
\end{abstract}

The results have shown that science teachers use the flipped classroom strategy frequently. Moreover, science teachers' attitudes towards developing higher-order thinking skills among students were at a high level, as the field of "critical thinking skills" came in the first place, followed by "problem-solving skills", however, "creative thinking skills" ranked last. Besides, the results have shown a strong correlation between science teachers 'use of the flipped classroom strategy and teachers' attitudes towards developing students' higher-order thinking skills. And, there are statistically significant differences in the science teachers' use of the flipped classroom strategy in teaching students of the higher basic stage in the Hebron governorate as well as in the science teachers' attitudes towards developing higher-order thinking skills among students of the higher basic stage in the Hebron governorate according to the gender variable for females, and according to the directorate variable for the directorate North Hebron.

given the findings of the study; The researcher recommended that it is necessary to provide means of support to encourage teachers to employ modern technologies in teaching thinking. It is also necessary to conduct more studies dealing with the relationship between teachers' attitudes towards developing higher thinking skills and employing other teaching strategies and to conduct evaluation studies to examine the effectiveness of flipped learning strategies in teaching thinking.

\section{العلاقة بين استخدام معلمي العلوم لاستراتيجية الصف المعكوس واتجاهاتهم نحو تنمية مهارات التفكير العليا لدى طلبة المرحلة الأسـاسية العليا في محافظة الخليل حنين محمود طه بستنجي \\ مديرية التربية والتعليم جنوب الخليل || وزارة التربية والتعليم || فلسطين فيني}


المستخلص: هدفت الدراسة إلى التعرف على العلاقة بين استخدام معلمي العلوم لاستراتيجية الصف المعكوس واتجاهاتهم نحو تنمية

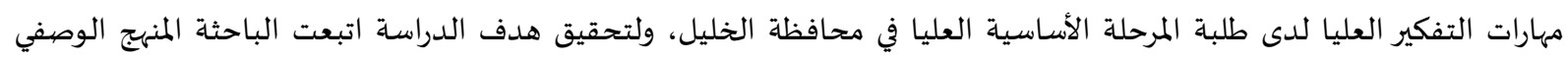
التحليلي؛ حيث قامت بتصميم استبانة لقياس مدى استخدام معلمي العلوم لاستراتيجية الصف المعكوس، واستبانة أخرى لقياس اتجاهات معلمي العلوم نحو تنمية مهارات التفكير العليا لدى طلبة المرحلة الأسساسية العليا، وقامت بتطبيقهما إلكترونيًا على عينة عشوائية من معلمي العلوم في محافظة الخليل بلغ عددهم (136) معلمًا ومعلمة في جميع مديريات محافظة الخدات الخليل.

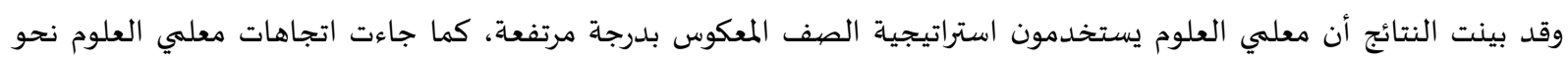

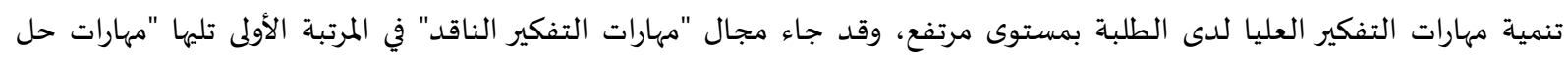

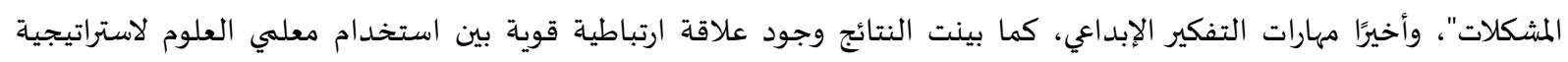
الصف المعكوس واتجاهات المعلمين نحو تنمية مهارات التفكير العليا لدى الطلبة، ووجود فروق دالة إحصائيًا في استخدام معلمي الحيات العلوم لاستراتيجية الصف المعكوس في تدريس طلبة المرحلة الأساسية العليا في محافظة الخليل، وكذلك في اتجاهات معلمي العلوم نحو

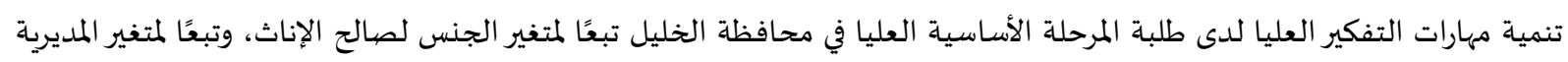

لصالح مديرية شمال الخليل. وفي ضوء النتائج التي توصلت إلها الدراسة؛ أوصت الباحثة بضرورة توفير وسائل الدعم لتشجيع المعلمين على توظيف التقنيات

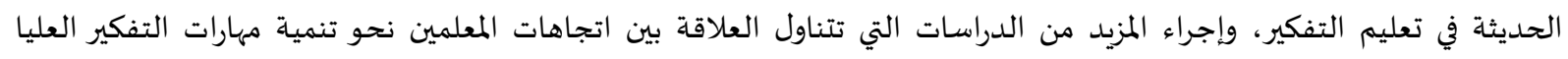
وتوظيف استراتيجيات تدريسية أخرى، وإجراء دراسات تقويمية لفحص مدى فعليم فعالية استراتيجيات التعلم المقلوب في تعليم التفكير. الكلمات المفتاحية: مهارات التفكير العليا؛ الصف المعكوس، العلوم، المرحلة الأساسية العليا.

المقدمة.

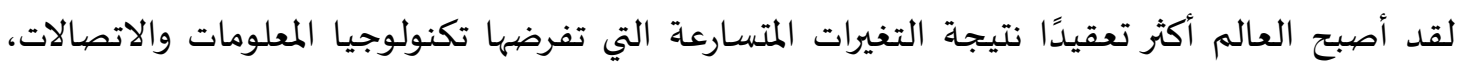

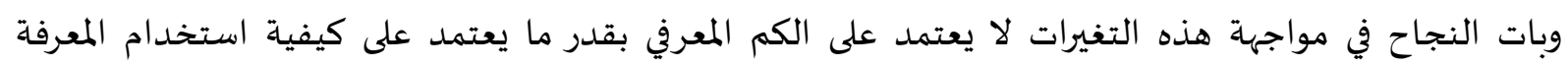

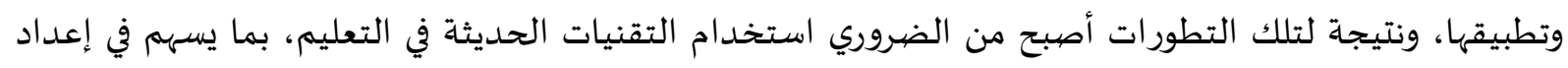
الطلبة وتأهيلهم لمواكبة تطورات العصر. وتعد استراتيجية الصف المعكوس إحدى الصيخ المعاصرة للتعلم المدمج والمنتشرة في المؤسسات التعليمية

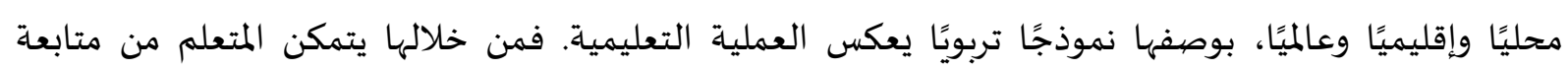

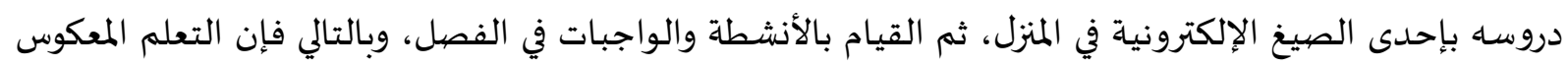

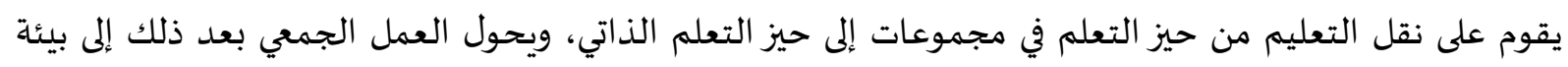
تعلم تفاعلية ودينامية (السعيدي، 2018). وقد أصبح تعليم التفكير في الآونة الأخيرة شعارًا تنادي باه كل الأنظمة التعليمية في العالم، ورغم أنه لا لا العاديا يوجد هناك اتفاق على الكيفية التي يفضل أن يتم تعليمه بواسطتها، إلا أن هناك اتفاقًا بين التربويين على أهميته الأنها

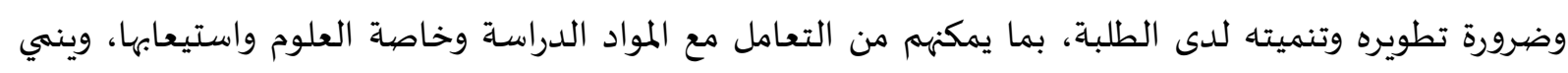

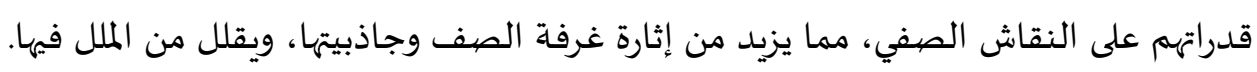

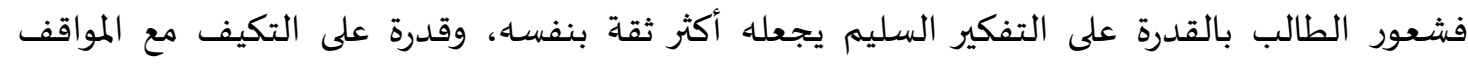

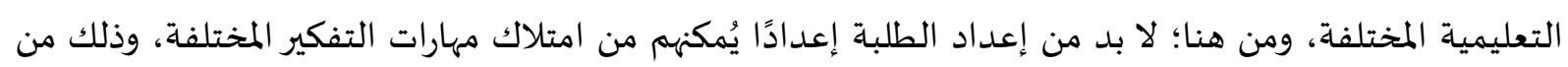

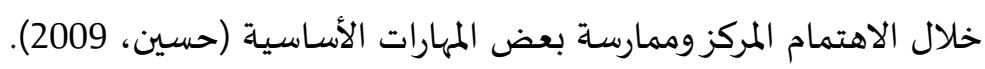

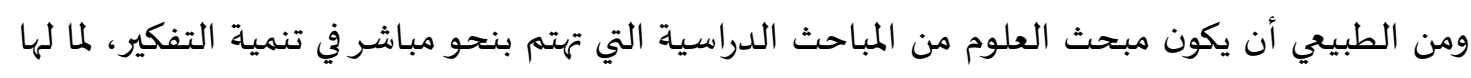

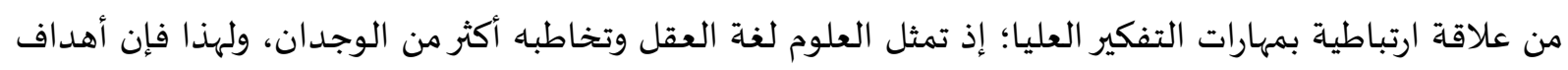

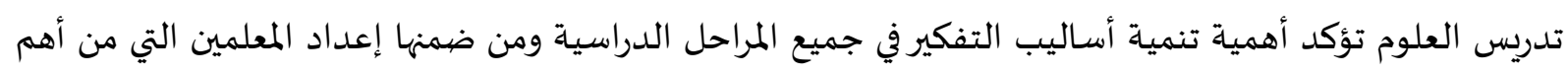


أهدافها إكساب الطلبة لأساليب التفكير من اعتماد الأسلوب العلمي وتحليل الموقف والتفكير بموضوعية واعتماد التفكير المنطقي والاستنتاجي وابتكار أساليب جديدة لحل المسابي المسائل (التميهي، 2016).

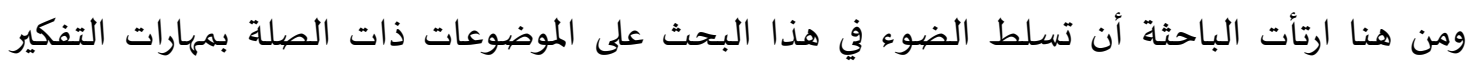

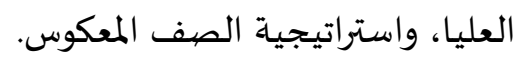

مشكلة الدراسة:

لم يقتصر تأثير العلوم على تغيير مظاهر البيئة المادية فحسب، بل أثرت على عاداتنا وتقاليدنا وسلوكنا

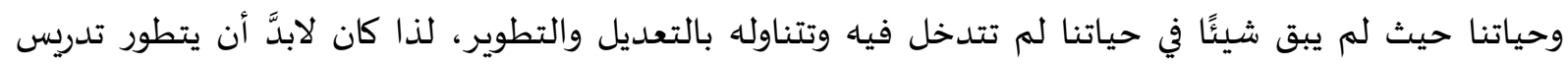

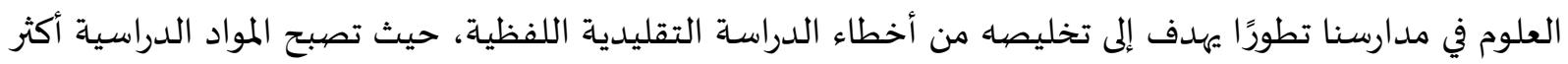
صلةً بحياة الطالب وتستهدف تعديل أسلوب التفكير لدياه، وتعديل السلوك بما يتفق مع مقتضيات الحياة العملية السليمة (العلواني، 2018).

ويشير واقع منهاج العلوم وطرائق تدريسها إلى تركيزها على تعلم الحقائق والمفاهيم والمعلومات وتذكرها

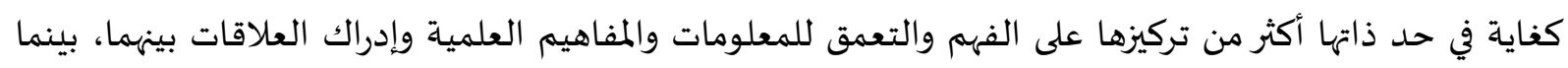

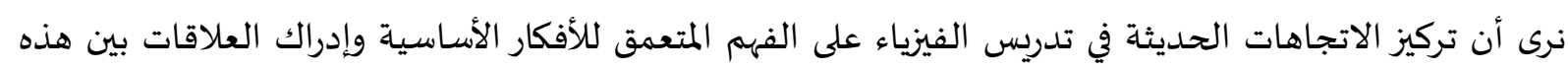

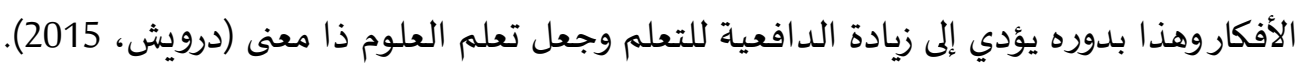

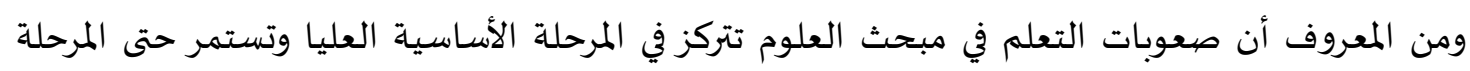

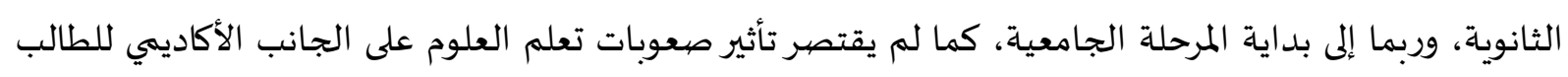
بل امتد إلى حاجاته اليومية والعلمياة. ومن هنا نستنتج أن المشكلة لا تكمن حقًا في صعوبة مبحث العلو العلوم بل في طرق تدريسها، والتي تزيد الأمور

$$
\text { تعقيدًا ويُنفِر الطلبة من تعلمها (غانم، 2010). }
$$

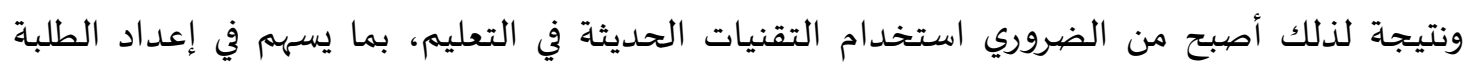

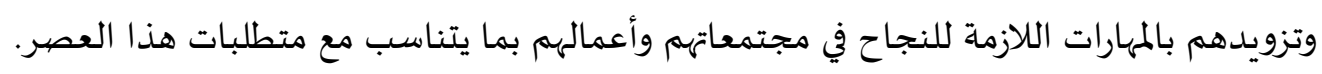
وكان من أهم تلك التقنيات التي بزغ فجرها، وضجت بها أصهوات التربويين ما يسمى بالتعلم المقلوب

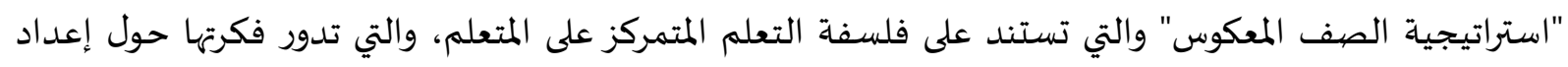

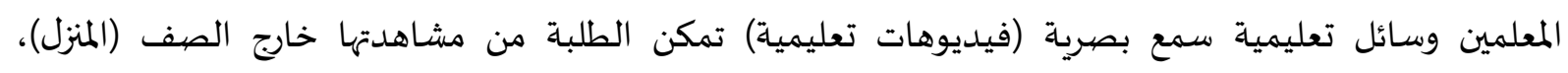

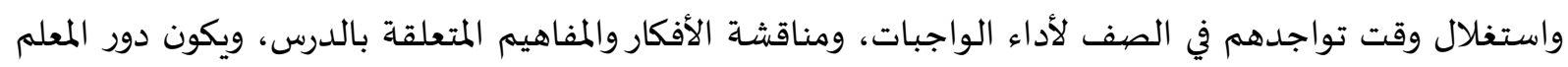
تزويد الطلبة بتغذية راجعة، وحل المشكلات. وتشير جامعة الطائف (2016) إلى أن أكثر ما يميز استراتيجية الصف وحلف المعكوس هو جذب المبات الطلبة، وتعزيز

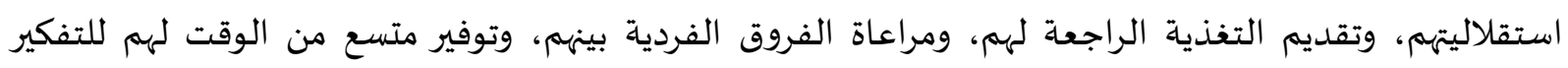

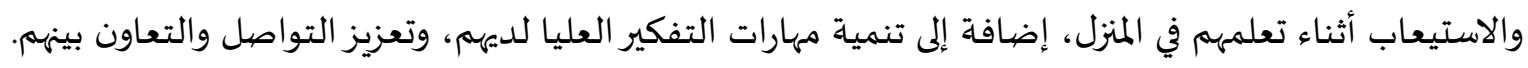
وعليه؛ فإن مشكلة الدراسة تنحصر في السؤال الرئيس الآتي:

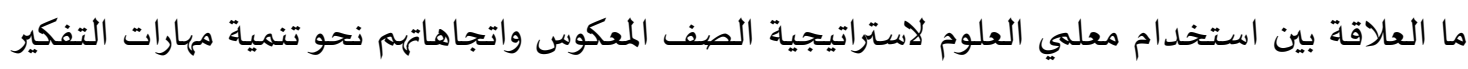
العليا لدى طلبة المرحلة الأساسية العليا في محافظة الخليل؟ معلئ العلوم لاستراتية 
تتحدد مشكلة الدراسة بالأسئلة الآتية:

1- ما واقع استخدام معلمي العلوم لاستراتيجية الصف المعكوس في تدريس طلبة المرحلة الأساسية العليا في باستية

محافظة الخليل؟ - افع

2- ما اتجاهات معلمي العلوم نحو تنمية مهارات التفكير العليا لدى طلبة المرحلة الأسساسية العليا في محافظة

الخليل؟

3- هل توجد علاقة دالة إحصائيًا بين استخدام معلمي العلوم لاستراتيجية الصف المعكوس واتجاهاتهم نحو

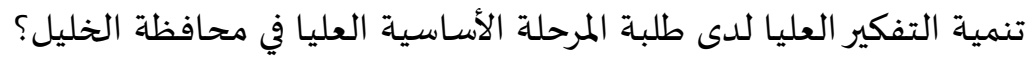

4- هل توجد فروق دالة إحصائيًا في استخدام معلمي العلوم لاستراتيجية الصف المعكوس في تدريس طلبة

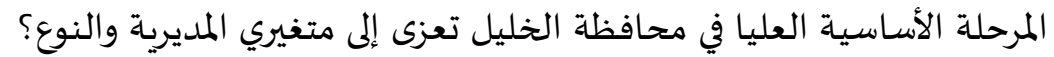

5- هل توجد فروق دالة إحصائيًا في اتجاهات معلمي العلوم نحو تنمية مهارات التفكير العليا لدى طلبة المهاتيات المرحلة

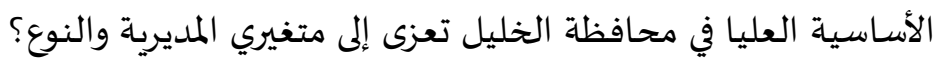

أهداف الدراسة:

تسعى الدراسة إلى تحقيق الأهداف التالية:

1. التعرف إلى واقع استخدام معلمي العلوم لاستراتيجية الصف المعكوس في تدريس طلبة المرحلة الأسـاسية

العليا في محافظة الخليل.

2. التعرف إلى اتجاهات معلمي العلوم نحو تنمية مهارات التفكير العليا لدى طلبة المرحلة الأساسية العليا في محافظة الخليل.

3. بيان العلاقة الارتباطية بين استخدام معلمي العلوم لاستراتيجية الصف المعكوس واتجاهاتهم نحو تنمية التفكير العليا لدى طلبة المرحلة الأساسية العليا في محافظة الاتيانة الخليل.

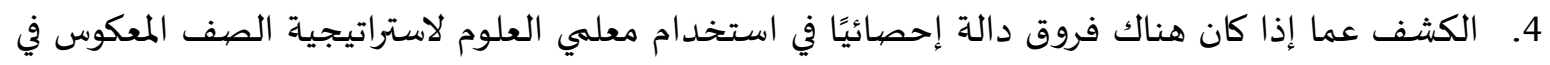

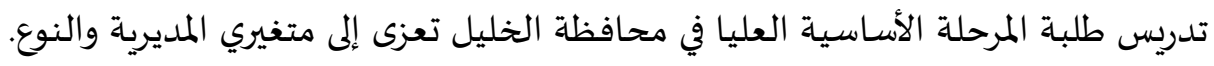

5. الكشف عما إذا كان هناك فروق دالة إحصائيًا في اتجاهات معلمي العلوم نحو تنمية مهارات التفكير العليا لدى طلبة المرحلة الأساسية العليا في محافظة الخليل تعزى إلى متغيري المديرية والنوع.

أهمية الدراسـة: (أهم:

تكمن أهمية الدراسة الحالية في:

1. قلة البحوث التي تناولت الكشف عن العلاقة بين درجة استخدام المعلمين لاستراتيجية الصفف المعكوس، واتجاهاتهم نحو تنمية مهارات التفكير العليا لدى الطلبة.

2. تقدم الدراسة أداة مقترحة لقياس درجة استخدام معلمي العلوم لاستراتيجية الصف الصفات المعكوس.

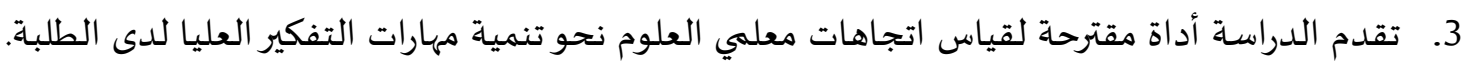

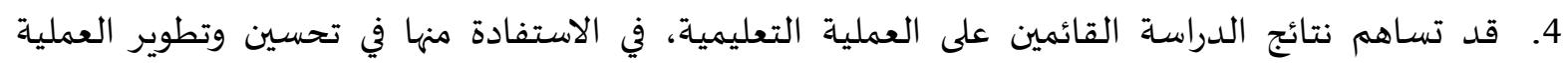
التعليمية، وتنمية مهارات التفكير العليا لدى الطلبة.

5. تعتبر هذه الدراسة إحدى الاتجاهات التي تدعو للاهتمام بنماذج التعليم المدمجي لمواكبة متطلبات العاتهات العصر. 
يمكن تعميم نتائج هذه الدراسة في نطاق الحدود التالية: الحدود الموضوعية: العلاقة بين درجة استخدام المعلمين لاستراتيجية الصف المعكوس، واتجاهاتهم نحو لموديم تنمية مهارات التفكير العليا لدى طلبة المرحلة الأساسية العليا. الحدود البشرية: عينة من معلمي العلوم في المرحلة الأساسية العليا في محافظة الخليل.

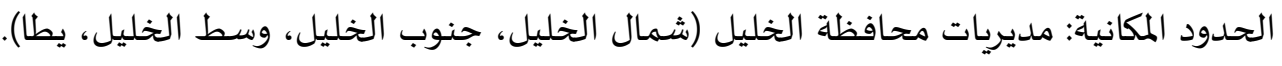

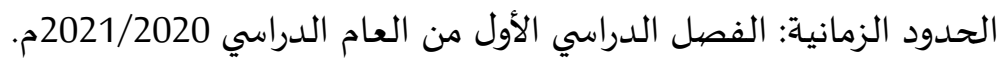

\section{مصطلحات الدراسة: -}

O يعرفه المركز العربي للبحوث التربوية لدول الخليج بأنه: "مقاربة يقوم فهها الطلبة بمشاهدة المحاضرات مسبقًا في

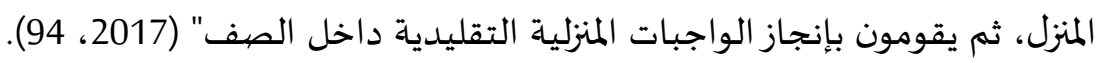

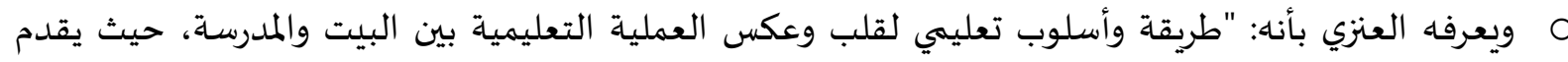

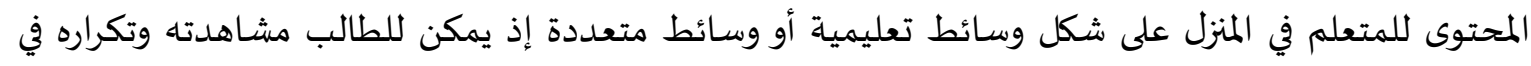

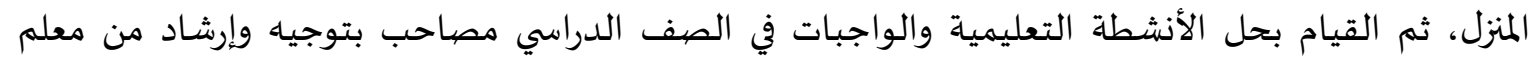

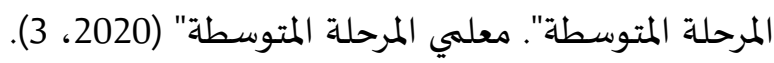
O مينما خليل وآخرون (2021، 509) فقد عرفوا الصف المعكوس بأنه: "استراتيجية تستند على فلسفة التعلم

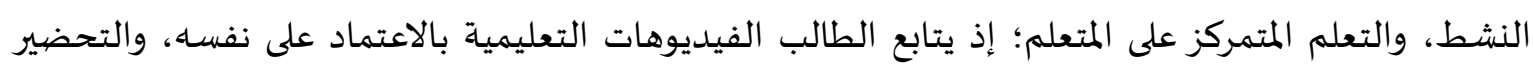

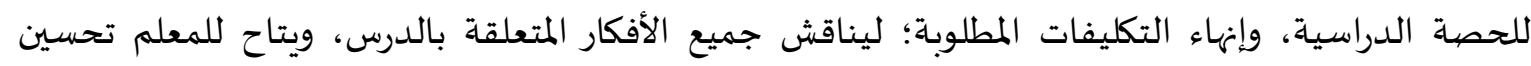
ممارساته التدريسية في الحصة الدراسية". التعريف الإجرائي للصف المعكوس: هو درجة ممارسة معلمي العلوم في المرحلة الأساسية العليا لأسلوب التعلم المارية

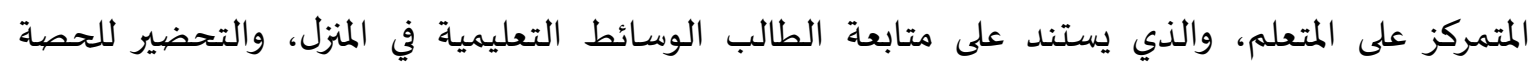

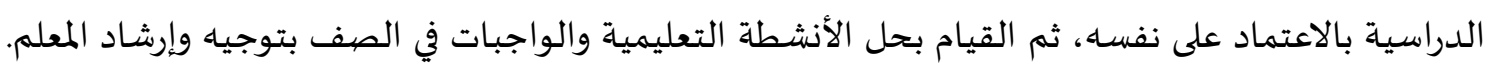

يعرف حنا وعلي مصطلح الاتجاه بأنه: سلوك الفرد نحو الموضوعات والمواقف الاجتماعية التي تختلف نحوها

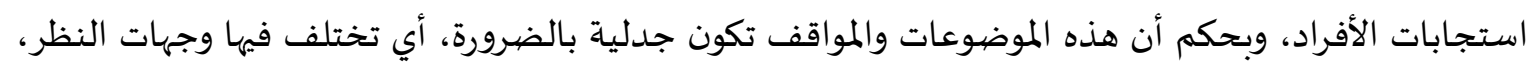

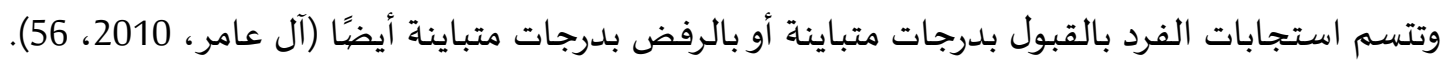
مهارات التفكير العليا: يعرف أبو رية مهارات التفكير العليا بأنها: "مجموعة من المهارات المعرفية التي تكون متضمنة تفاعليًا في عمليات

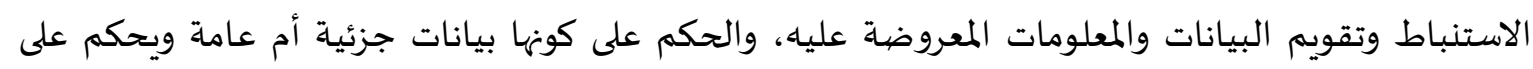

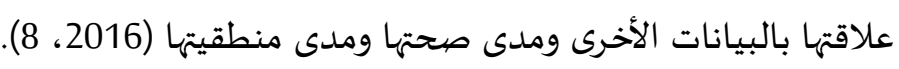

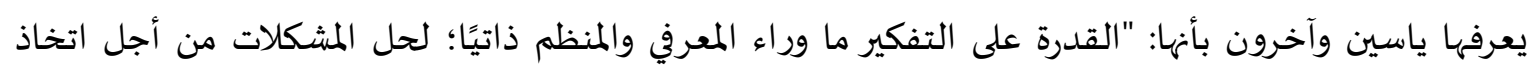

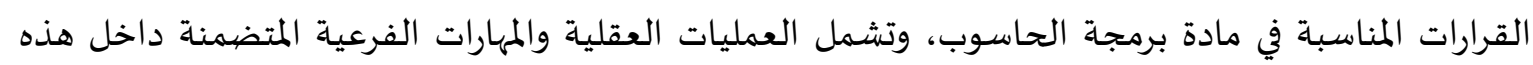

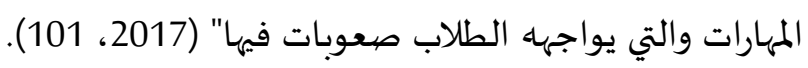


O بينما يعرفها كلق من حميد ومحمد بأنها: "مجموعة من العمليات والمهارات العقلية التي يستعملها الفرد عند

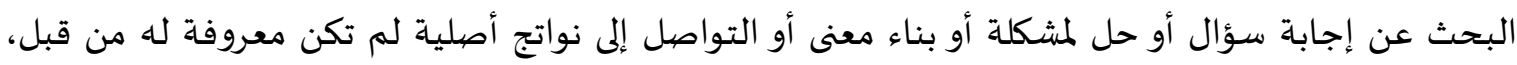

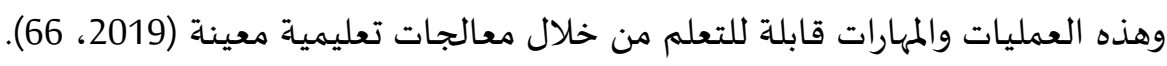
O التعريف الإجرائي لمهارات التفكير العليا: المواقف التي يظهرها معلم العلوم نحو مهارات التفكير الناقد، ومهارات

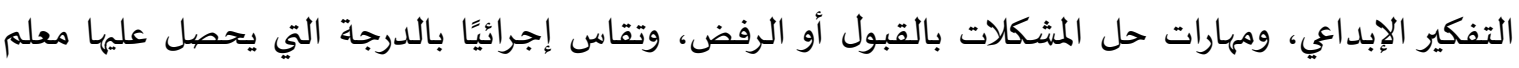

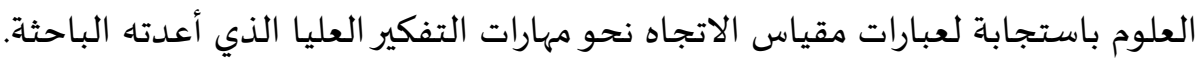

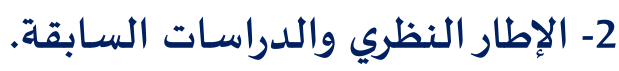

أولًا - الصف المعكوس.

مفهوم استراتيجية الصف المعكوس:

يعرف الصف المعكوس بأنه: استخدام أدوات الفيديو لتسجيل المحاضرات وإتاحتها للطلبة قبل الحضور

للمحاضرات الرسمية؛ حيث يتم توضيح المفاهيم الصعبة وحل المشكلات والإجابة على التساؤلات الصعبة داخل الماتل

الصف (Stone, 2012, P.1).

كما يعرف بأنه: استراتيجية تدعم مفهوم التعلم المتمركز حول الطالب؛ إذ يقوم الطلبة من خلالها

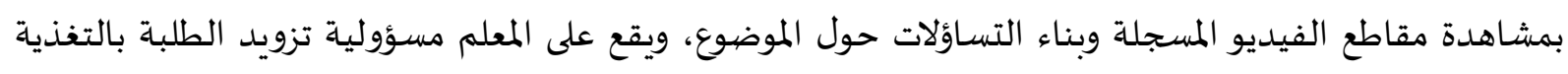
الراجعة، وحل المشكلات حول الموضوع (Bergmann and Sams, 2012, P.16-17). ويعرف أيضًا بأنه: استراتيجية تعليمية توظف التعلم غير المتزامن من خلال مشاهدة مقاطع الفيديوع

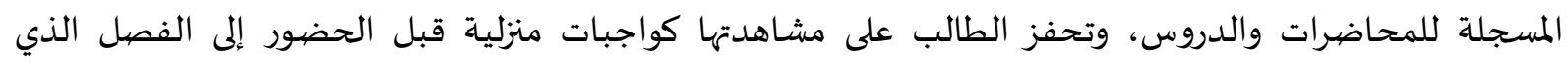

يخصص الوقت فياه للمشاركة الفعَّالة وحل المشكلات بشكل جماعي (Verleger and Bishop, 2013, P.2). ويعتبر الصف المعكوس أيضًا: منحى تعليمي يتم فيه الانتقال بالتدريس من مكان تعلم المجموعة إلى مكان المان المكان

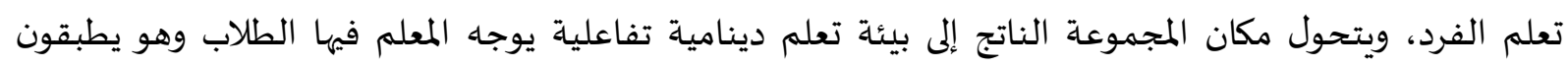

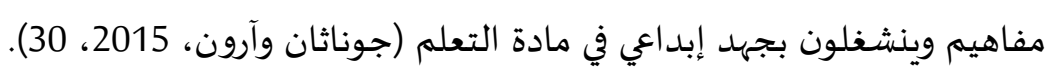

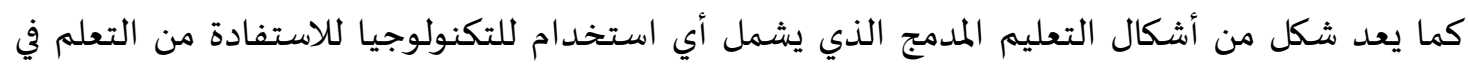

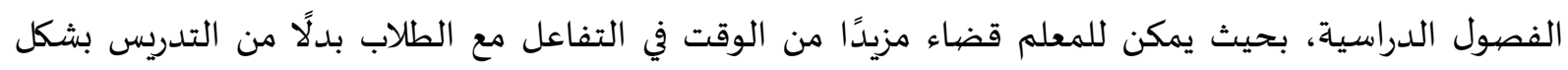

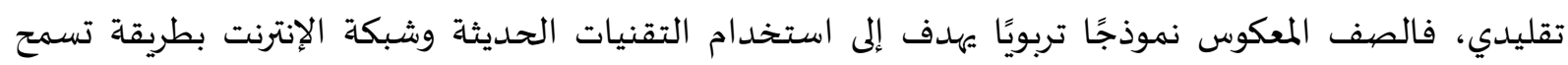

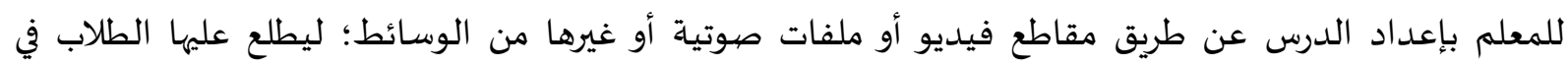

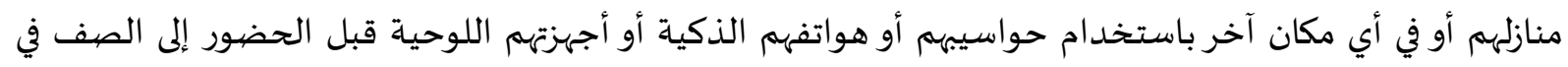

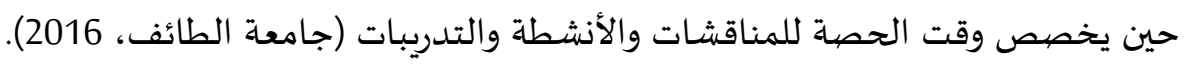

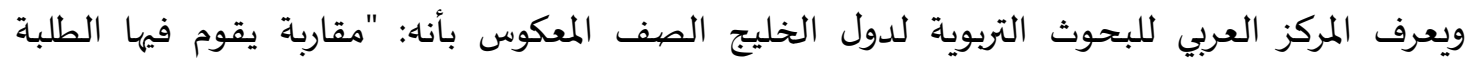

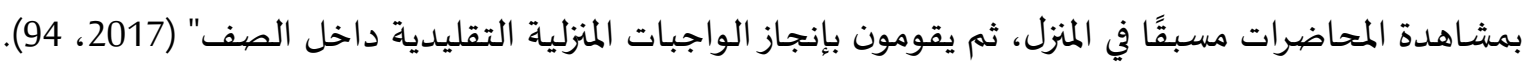

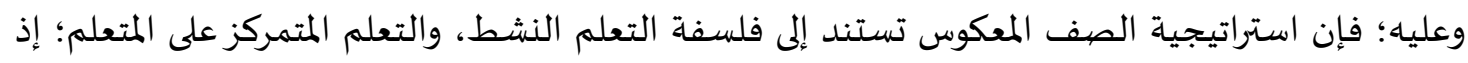
يتابع الطالب الفيديوهات التعليمية بالاعتماد على نفسه، والتحضير للحصية الدراسية، وإنهاء التكليفات المطلوبة؛ ليناقش جميع الأفكار المتعلقة بالدرس، ويتاح للمعلم تحسين ممارساته التدريسية في الحصية الدراسية (خليل وآخرون، 2021). 
مما سبق؛ لاحظت الباحثة وجود اتفاق بين جميع الباحثين حول مفهوم الصف المعكوس، حيث ركز الجميع على أن الصف المعكوس يقوم على فكرة مفادها أن يتحمل الطالب مسؤولية متابعة دروساه من خلئ خلال

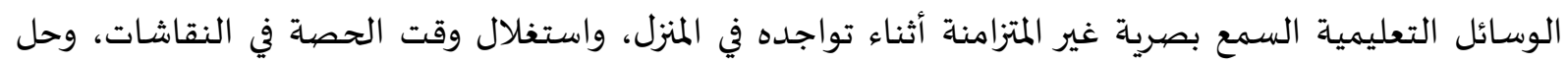

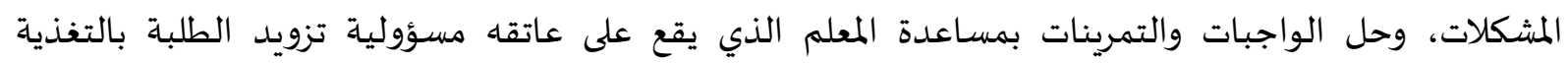
الراجعة والتوجياه والإرشاد.

وعليه؛ تُعرف الباحثة استراتيجية الصف المعكوس ولادف في هذا البحث بأنها: درجة ممارسة معلهي العلوم في

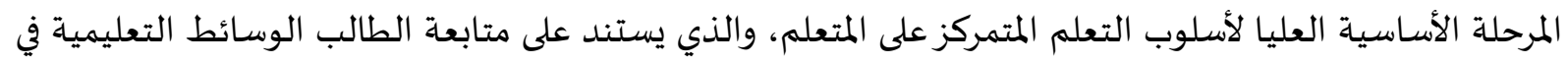

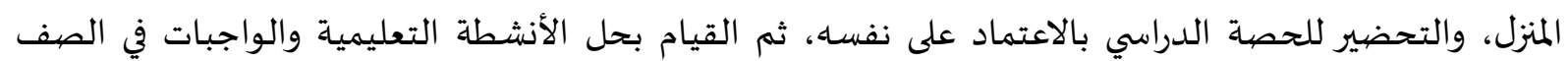
بتوجياه وإرشاد المعلم.

مميزات الصف المعكوس:

لاستراتيجية الصف المعكوس مميزات وإيجابيات تجذب كلًا من المعلمين والطلاب إلى التفاعل معها، ويمكن

$$
\text { إجمال تلك المميزات فيما يلي: }
$$

مميزات الصف المعكوس بالنسبة للمعلم:

- - تطور دور المعلم الملقن ليصبح موجهًا ومحفزًا ومرشدًا ومساعدًا.

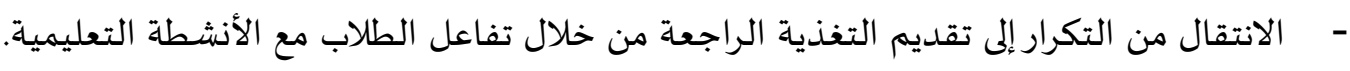

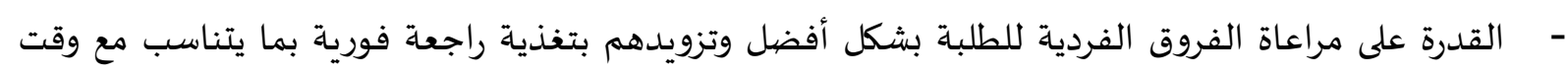
الحصة وقدرات كل طالب.

- الاستغلال الجيد لوقت الحصة؛؛ لتنفيذ الأنشطة التعليمية وتزويد الطلبة بتغذية راجعة فورية، تزيد من نشاط الطلبة وتفاعلهم مع المادة التعليمياة.

مميزات الصف المعكوس بالنسبة للبيئة التعليمية: - - - التوظيف الأمثل للتقنية الحديثة وأدواتها في العملية التعليمية. - - توفير بيئة تعليمية شيقة وممتعة تجذب الطلاب.

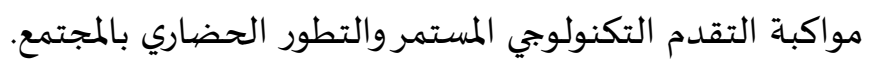

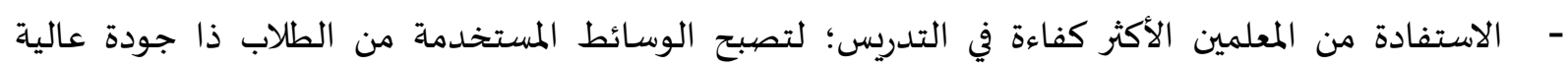
وفعالية كبيرة.

مميزات الصف المعكوس بالنسبة للطلبة: - جذب الطلبة نحو العملية التعليمية ليصبح مشاركًا فاعلًا. - تعزيز استقلالية المتعلم وتقديم التغذية الراجعة الفورية والتي تميز التعلم الذاتي الذي يفضله الطيه الطلبة.

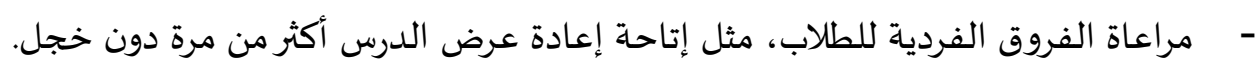
- يوفر للطلبة متسع من الوقت للتفكير والاستيعاب والتفكير الناقد والإيجابي أثناء تعلمههم في المنزل. - تنمية مهارات التفكير العليا، مثل التفكير الناقد ومهارات التواصل والتعاون بين الطلاب (جامعة الطائف، 
فيما يشير جوناثان وأرون (2014) إلى أن التعليم المقلوب يجعل المتعلم محور الأداء وليس المعلم، حيث

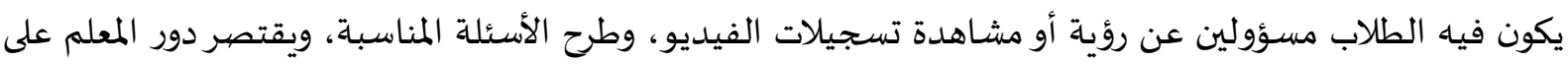
تقديم التغذية الراجعة، ويكون دور الطلبة هو التوصل إلى الاستخدام الأمثل لها، في فهم المفاهيم المطلوبة.

شروط نجاح الصف المعكوس: ولنجاح استراتيجية الصف المعكوس، لا بد من مراعاة التغيير في كيفية استخدام الوقت داخل الصف كاتف

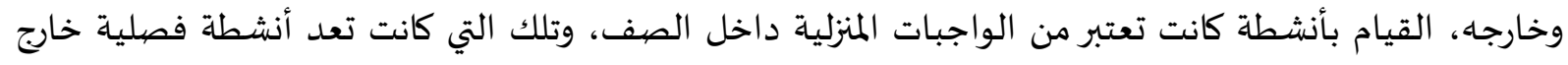

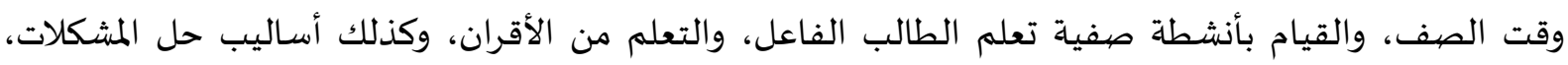

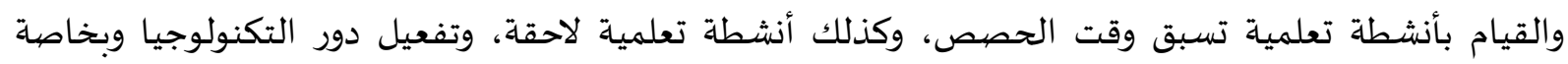
استخدام الفيديو التعليمي (Abeysekera and Dawson, 2014). كما يجب مراعاة التحديات والصعوبات التي قد تعترض تطبيق استراتيجية الصف المعكوس، ومن

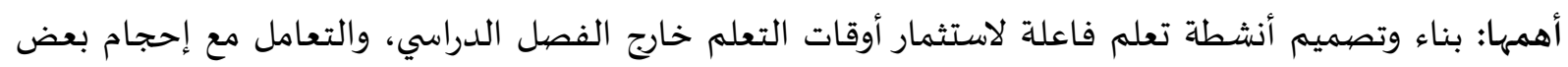

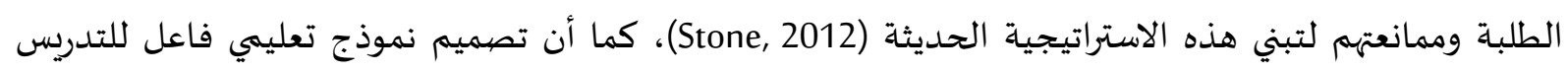
باستخدام الصف المعكوس قد يستهلك الكثير من الوقت والجهد، كما يتطلب تطبيق هذا النمط أيضًا الإعداد

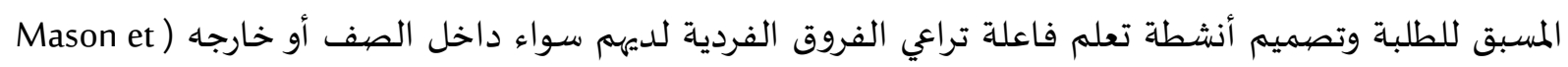

وللتغلب على مثل هذه التحديات ورفح كفاءة استراتيجية الصف المعكوس يقترح (Wagner et al, 2013)

بأن يقوم المعلم بتزويد الطلبة بأنشطة تعلم فاعلة ومتنوعة داخل الصف، الصفي بحيث تكون فردية وجماعية، وأن يتم

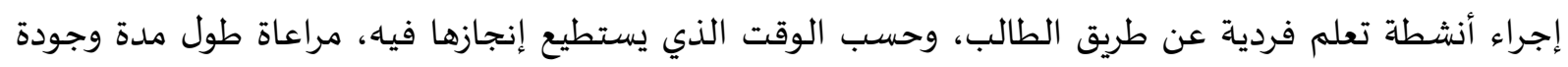

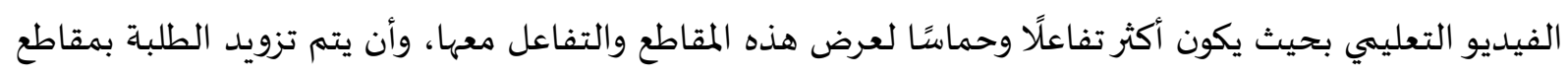

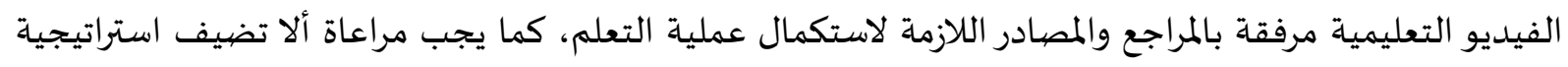

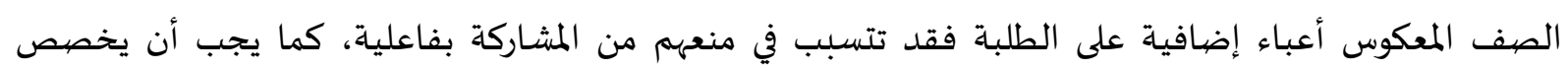

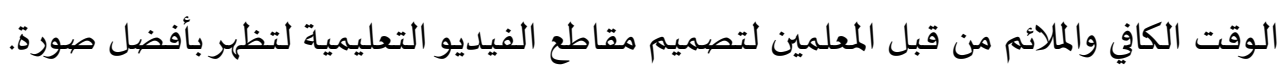
ولا بد أن يحتوي الصف المعكوس على نوعين أساسيين من الأنشطة التعليمية التعلمية، هما: التعلم

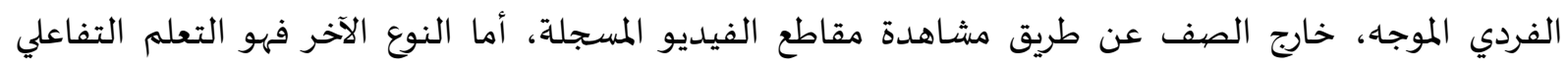

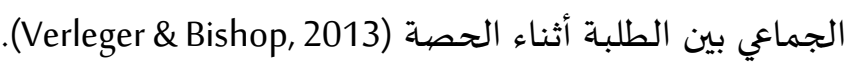

ثانيًا- مهارات التفكير العليا: يعد التفكير من أرقى السمات التي كرم الله بها الإنسان وميزه بها عن سائر المخلوقات، وقد حثَّ الله سبحانها وتعالى البشر على التفكيروالتعقل في كل ما حولهم، ومن هنا تبرز أهمية التفكيرواكتساب مهاراته في حياة الإنسان.

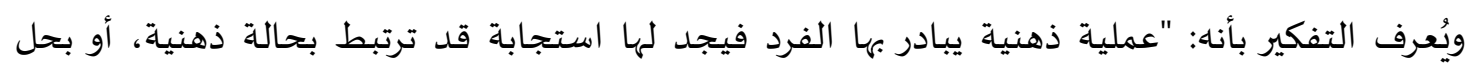

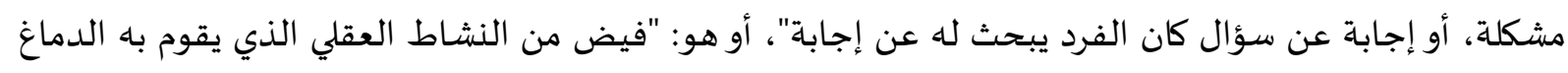

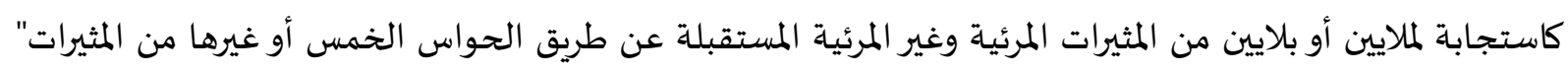

(عبد العزيز، 2009، 21). 
وتعرف مهارات التفكير العليا بأها: "مجموعة من المهارات المعرفية التي تكون متضيمنة تفاعليًا في عمليات

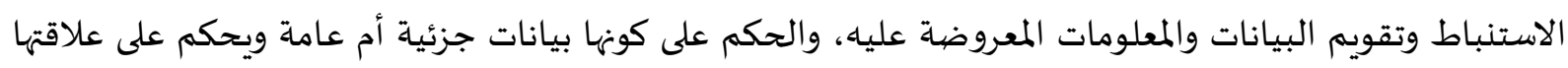

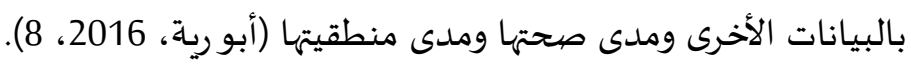

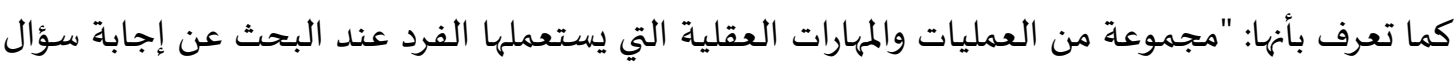

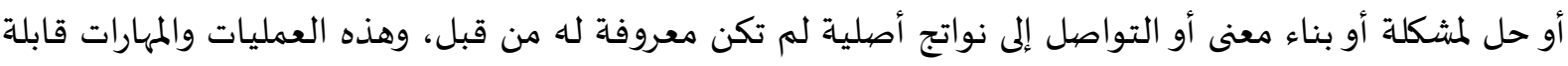

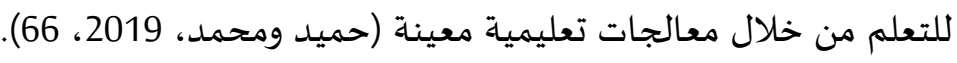

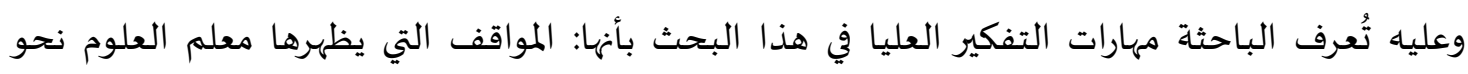

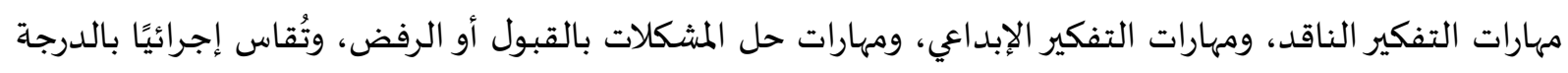

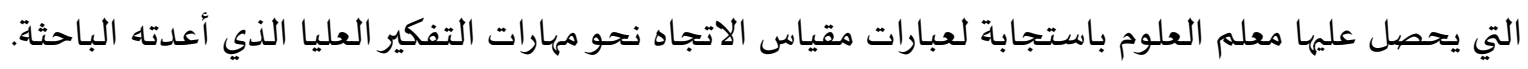

\section{أهمية تنمية مهارات التفكير العليا:}

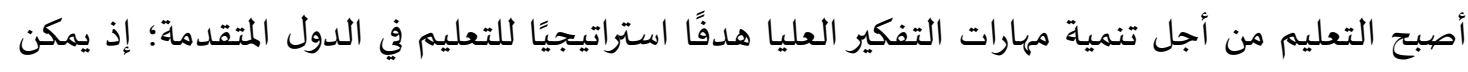

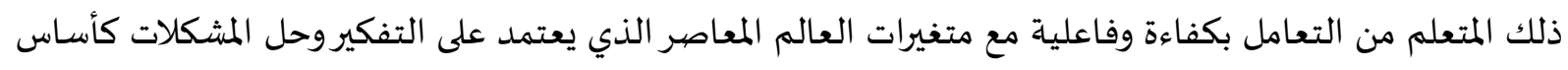

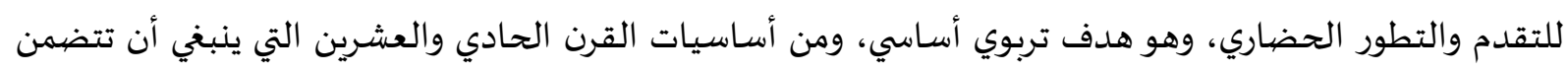

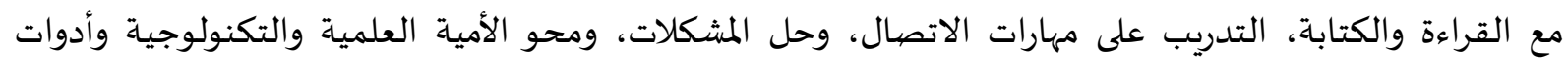

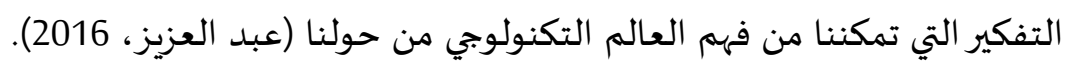

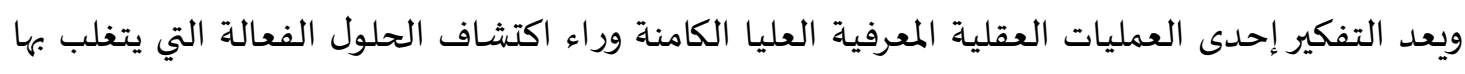

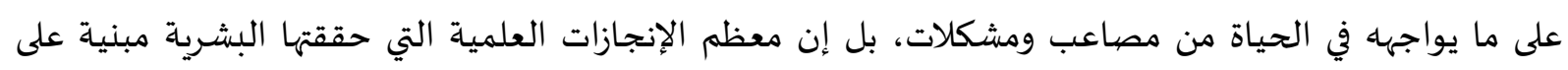

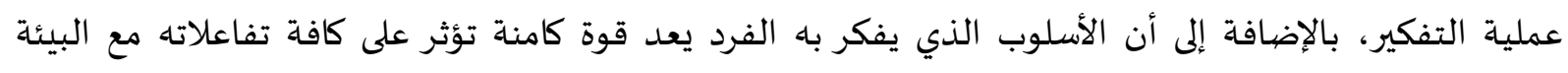
المحيطة باه (السراج، 2017).

كما يعد التفكير هو مصدر للعلم، والعلم مصددر لتعديل سلوك الإنسان، كما أن التفكير عملية لا يتم اكتسابها عفويًا، بل هي عملية موجهة، يتم اكتسابها بالتدريب والممارساة، حيث يتمثل التفكير بقدرة الإنسان على ولى

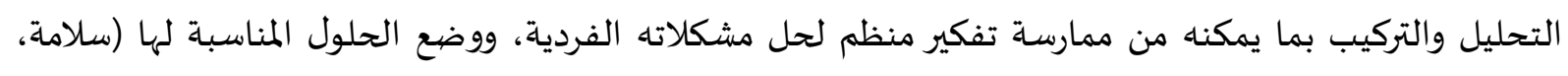

وعليه؛ فإن الحاجة إلى تعليم مهارات التفكير وتعلمها تتأكد بأمرين، الأول: اعتبار التفكير مهارة، وأي مهارة

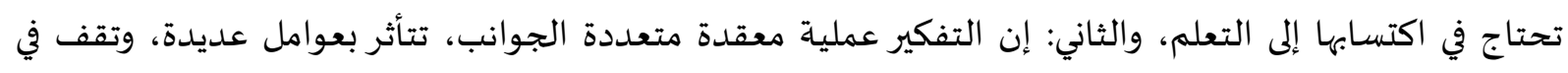
طريق العقبات.

خصيائص عملية التفكير: ت تمني تتميز عملية التفكير بأنها: نشاط عقلي غير مباشر؛ فلكي يتوصل الإنسان إلى إقرار علاقات بين الأشياء، فإنه إنها

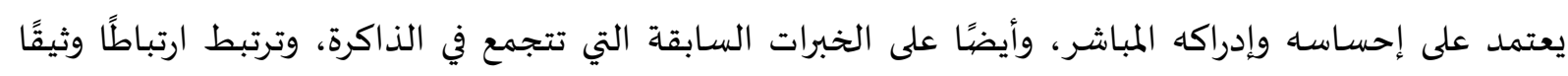

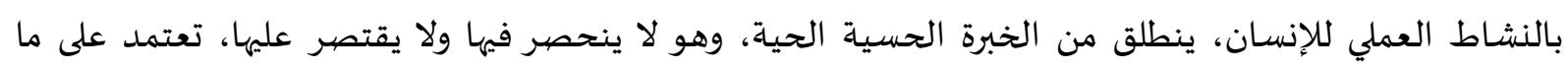

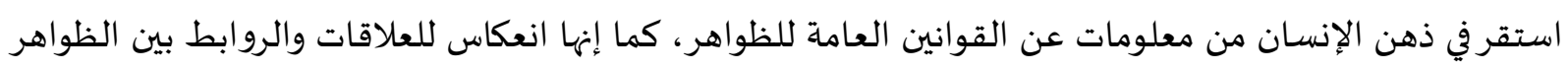
والأحداث والأشياء، في شكل لفظي ورمزي، ويعتبر دالة الشخصياة، فالتفكير هو جزء عضومات عضوي وظيفي من البنية الكلية

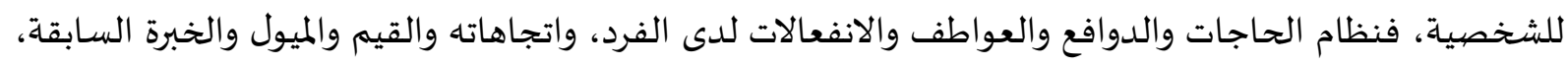


والإحباطات والإشباعات في حياته، كل هذا ينعكس على تفكيره ويوجهاه، بل إن أسلوب الفرد في التفكير، يتحدد من أسلوبه في الحياة بصفة عامة (أبو جلالة، 2012؛ عبدانه الأشباعات في العزيز، 2016). وعليه فإن تعليم مهارات التفكير هو بمثابة تزويد الفرد بالأدوات التي يحتاجها حتى يتمكن من من التهات التعامل

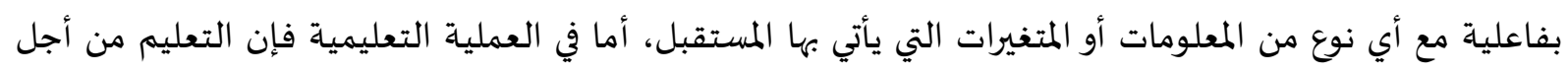
التفكير يرفع من درجة الإثارة والجذب للخبرات الصفية، ويجعل دور الطعات المتفرات التباتي إيجابي وفاعل.

أنواع التفكير:

صنف (فتحي وجروان، 2003) مهارات التفكير إلى ثلاثة مستويات رئيسة تتمثل فيما يلي:

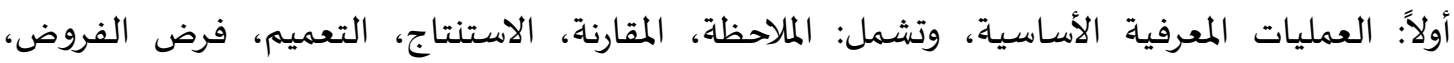

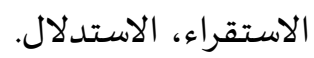

ثانيًا: العمليات المعرفية العليا: وتشمل حل المشكلات، إصلاءل إصدار الأحكام، التفكير النقدي، التفكير الإبداعي.

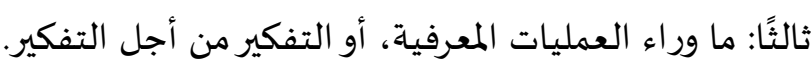

وستركز الباحثة في هذا البحث على العمليات المعرفية العليا الثلاث التالية:

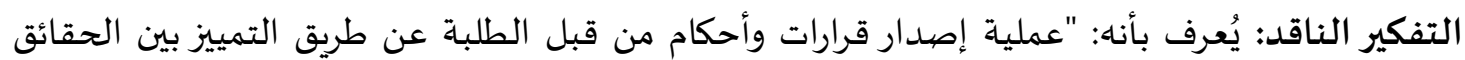

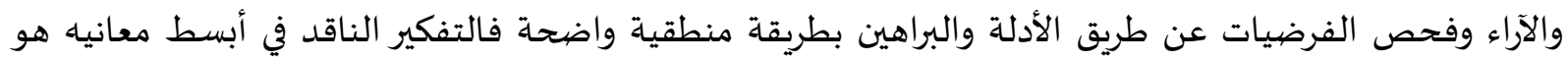

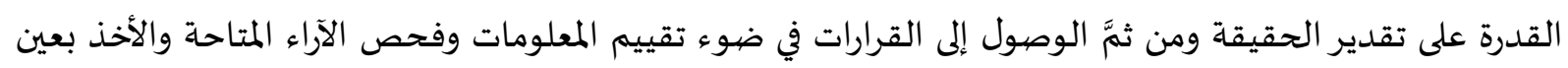

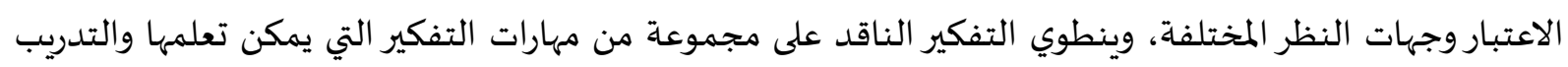

عليها وإجادتها" (القطيطي، 2016، 97). التفكير الإبداعي: يُعرف بأنه: "عملية ذهنية تتكامل فيها قدرات الطلاقة والمرونة والأصالة والحساسية

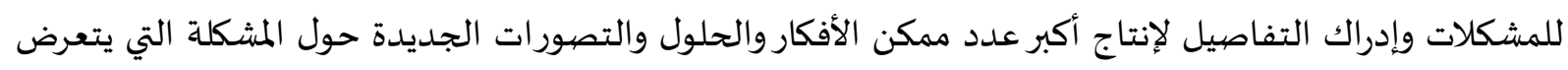

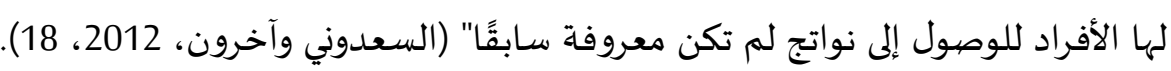

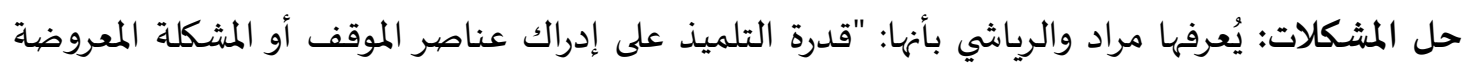

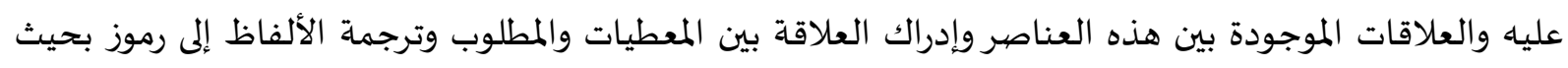

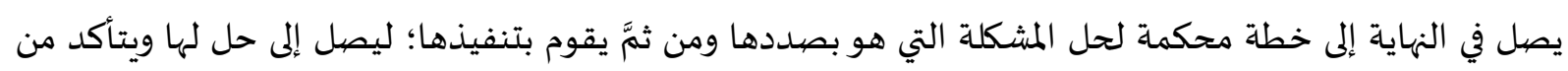

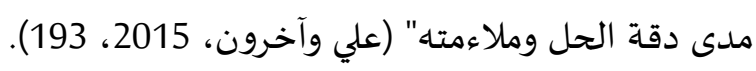

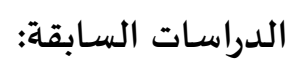

تعددت الدراسات التي تناولت متغيرات موضوع الدراسة، منها:

أ- دراسات ذات صلة بالصف المعكوس: - دراسة (خليل وآخرون، 2021) التي هدفت إلى التعرف على الانعكاسات الناتجة عن توظيف استراتيجية

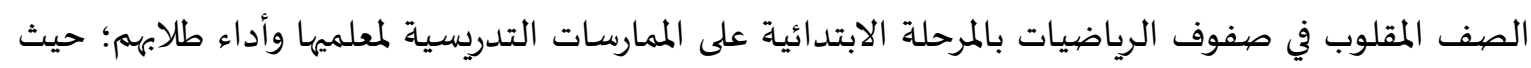

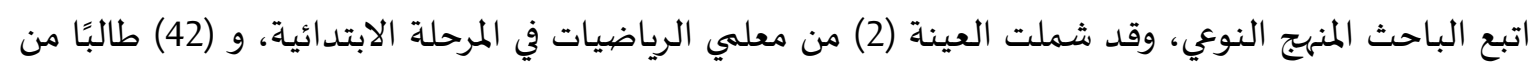

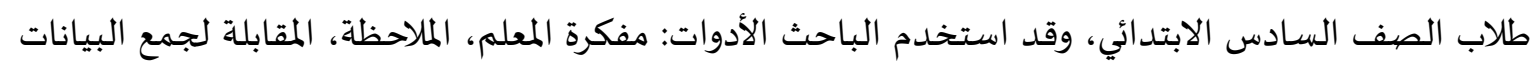

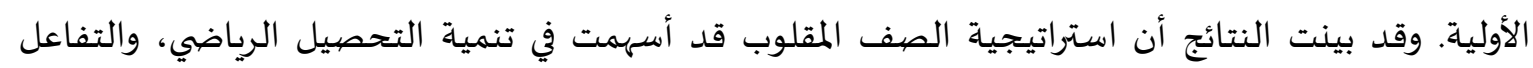


الصفي، والاتجاه نحو تعليم الرياضيات وتعلمها، وإتاحة الفرصة للمعلمين بتناول مجموعة من أفكار الدرس،

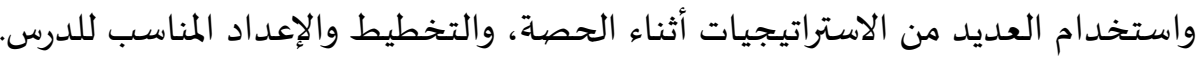
أما دراسة (عباس، 2020) فقد هدفت إلى معرفة اتجاهات أعضاء هيئة التدريس نحو التدريس باستراتيجية

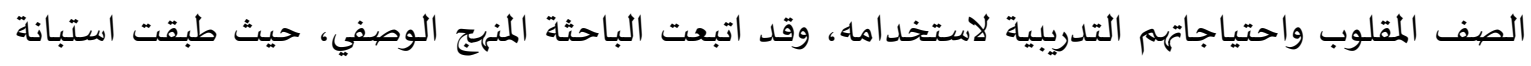

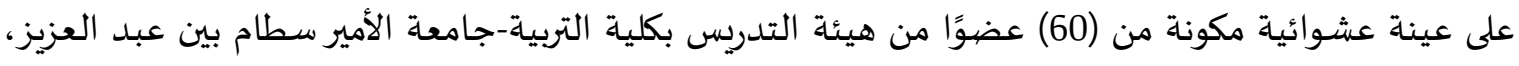

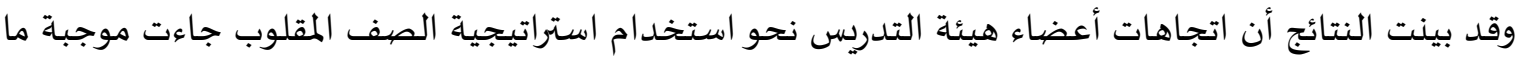

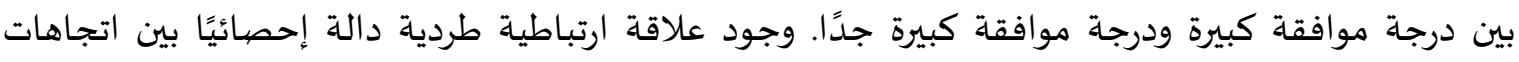
أعضاء هيئة التدريس نحو التدريس بنموذج الصف المقلوب وبين احتياجاتهم التدريبية اللازمة لاستخدامهاء. وتناولت دراسة (العنزي، 2020) استقصاء واقع تطبيق معلمي المرحلة المتوسطة لاستراتيجية الصف المباء المقلوب؛ حيث اتبع الباحث المنهج الوصفي المستي، وطبق استبانة على عينة مكونة من (194) معلمًا من معلمي المرحلة

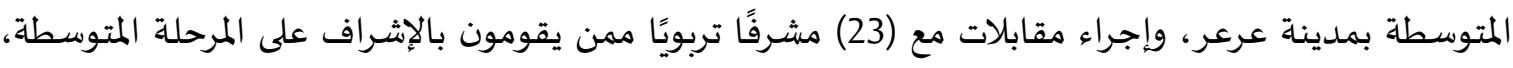

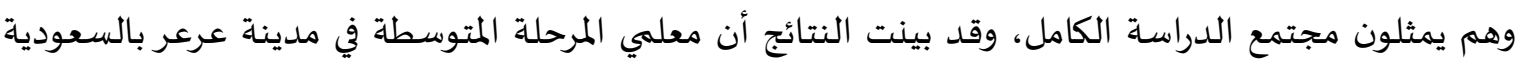

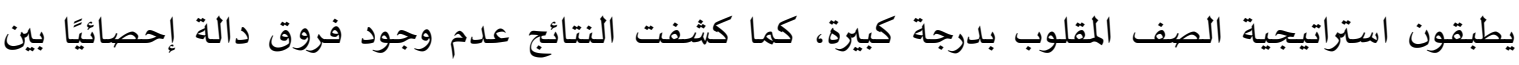

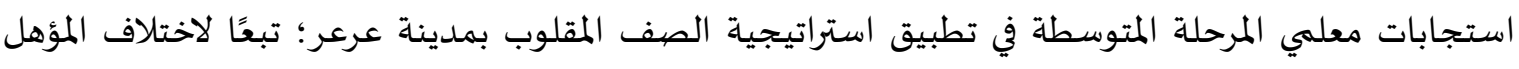
العلمي وسنوات الخبرة. فيما ركزت دراسة (المجالي، 2019) على معرفة درجة استخدام استراتيجية التعلم المدمج لدى معلمي المرحلة

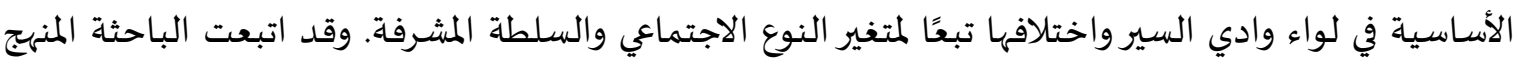
الوصفي، وقامت بتطبيق استبانة على عينة مكونة من (350) معلمًا ومعلمة من معلمي المرحلة الأساسية العليا

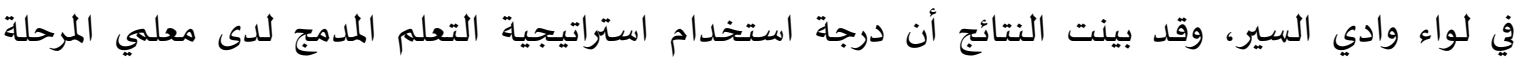

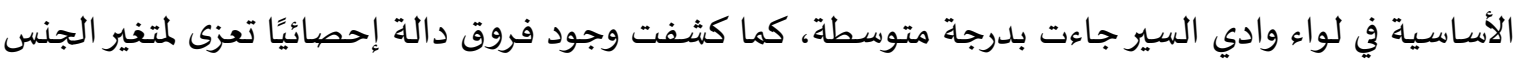

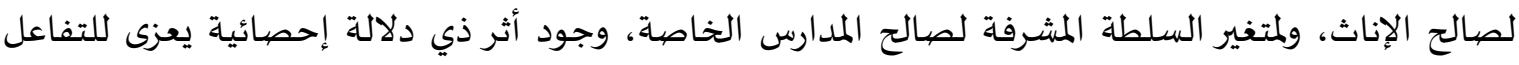
بين النوع الاجتماعي والسلطة المشرفة.

ب- دراسات ذات صلة بمهارات التفكير العليا: هدفت دراسة (المالكي والشهري، 2020) إلى تحديد مهارات التفكير العليا التي يتعين على معلمي الرياضيات

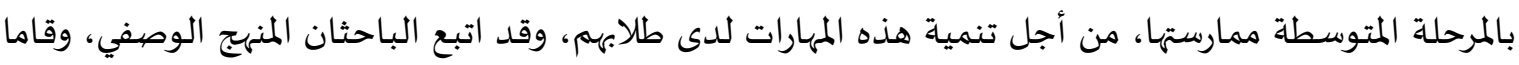

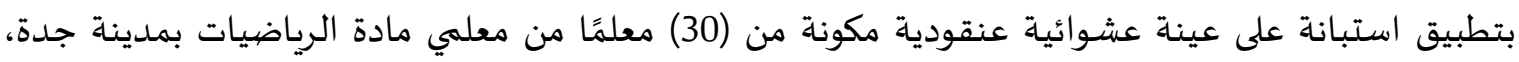

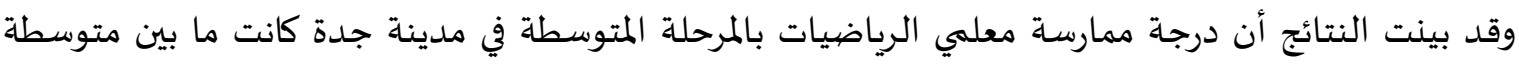

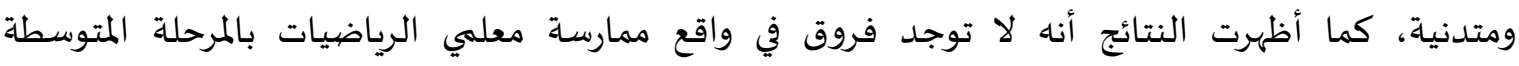

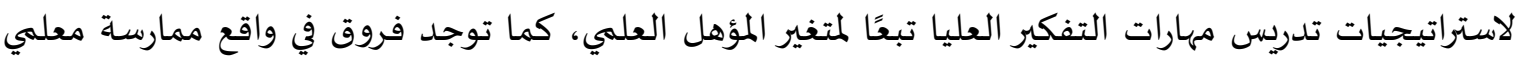

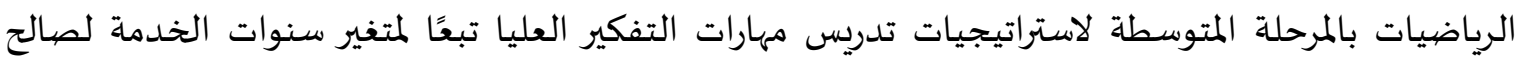
المعلمين الذين كانت عدد سنوات خدمتهم (من 10 على أقل من 20 سنة).

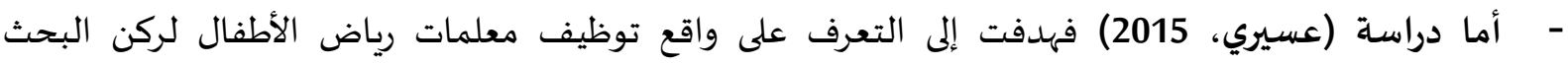

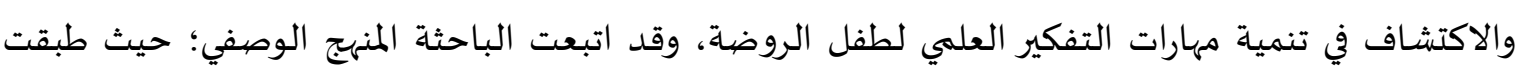

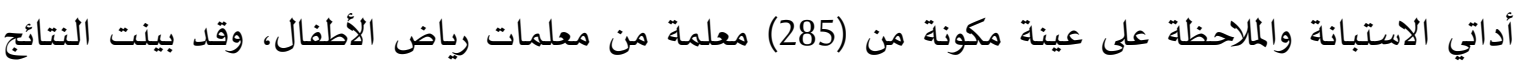


وجود اتجاهات إيجابية لدى المعلمات نحو ركن البحث والاكتشاف؛ كما لديهن إيمان بدوره في تنمية مهارات التفكير العلمي لدى الطفل.

- مما هدفت دراسة (شـاهين، 2014) إلى معرفة اتجاهات معلمي الفنون نحو استخدام خرائط العقل لتنمية مهارات التفكير الإبداعي، وقد اتبعت الباحثة المنهج الوصفي، وطبقت الاستبانة على عينة مكونة من (122)

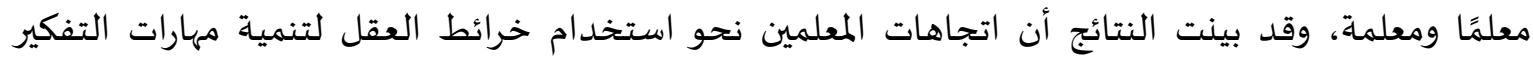

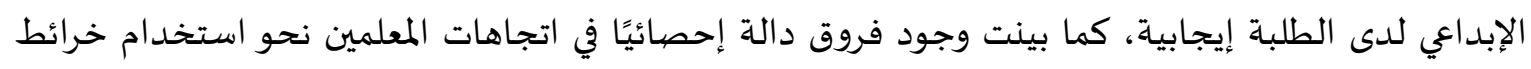

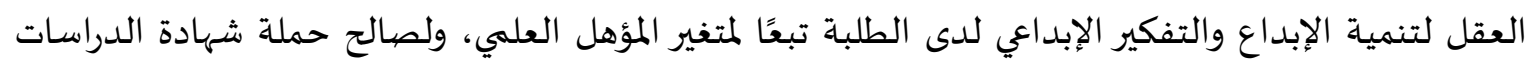

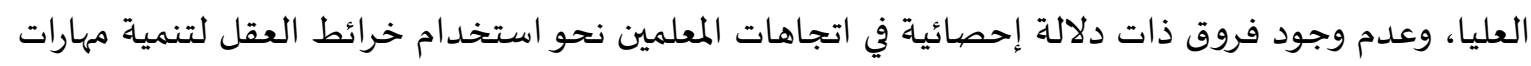

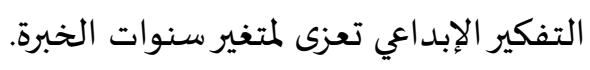

وقد ركزت دراسة (العساف، 2013) على معرفة اتجاهات معلمي الدراسات الاجتماعية نحو تنمية مهارات

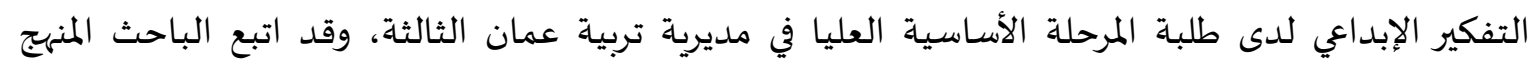

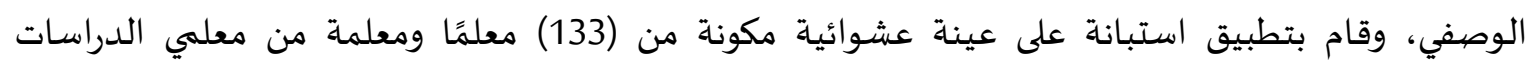

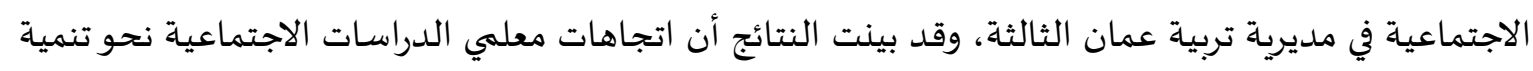

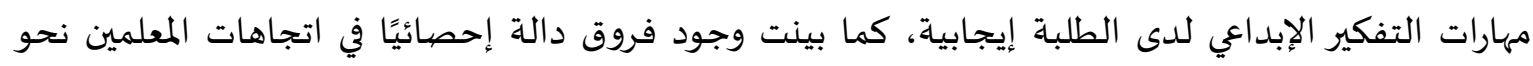

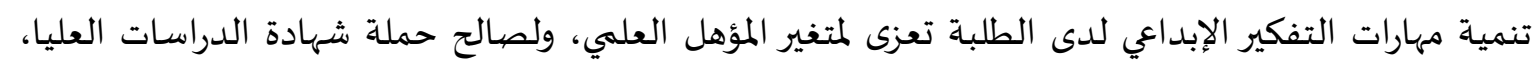

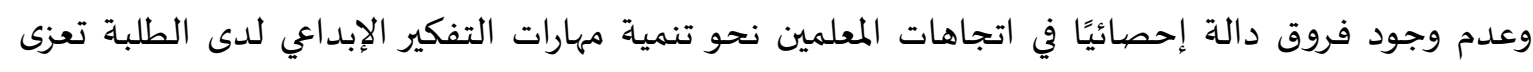

لمتغيري الخبرة (سنوات الخدمة).

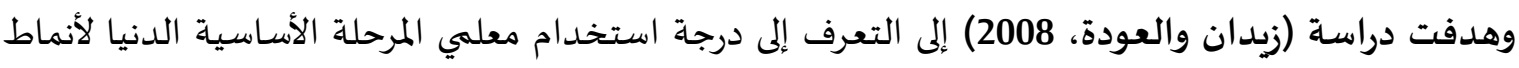

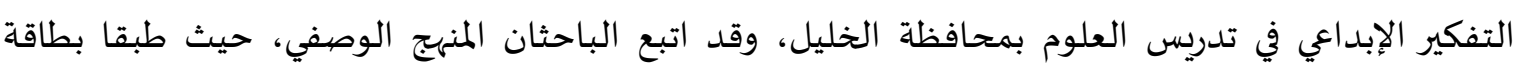

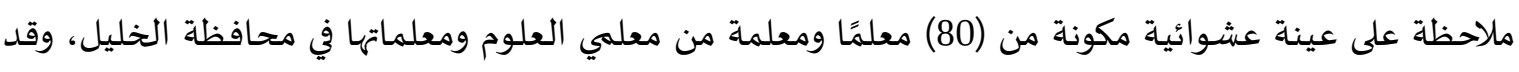

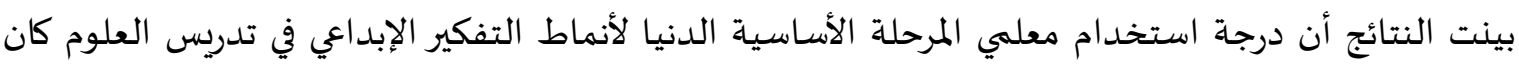

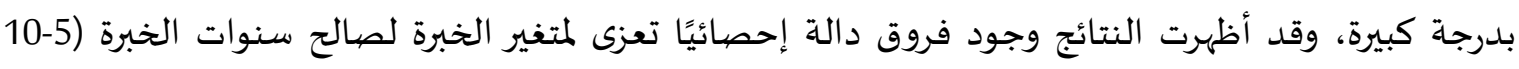
سنوات) و (أكثر من 10 سنوات) وقل الفهرت.

التعليق على الدراسـات السابقة:

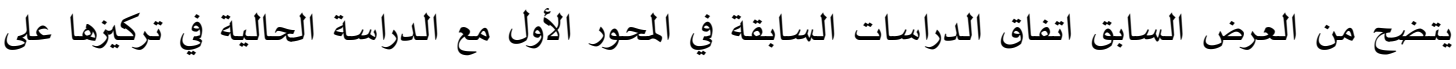

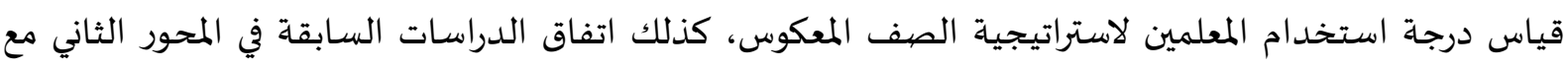

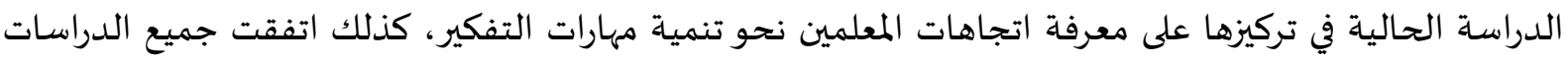

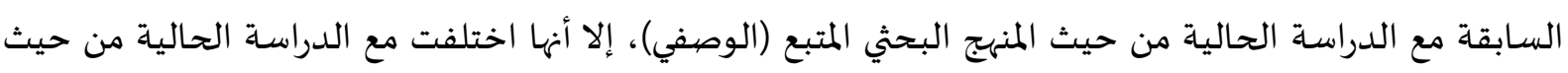

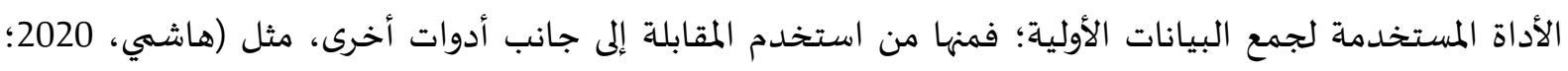

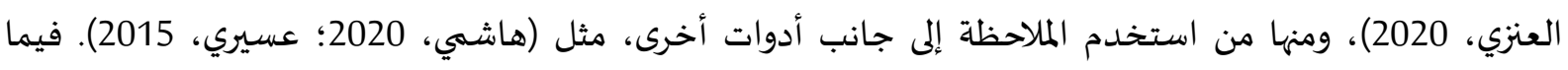
اتفقت الدراسات التالية (عباس، 2020؛ العنزي، 2020؛ المالكي والشهري، 2020؛ 2020؛ المجالي، 2019 2013، عسيري، إني، 2015؛

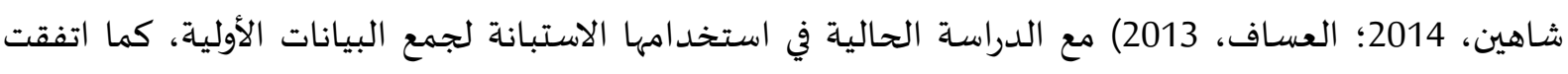
جميع الدراسات السابقة مع الدراسة الحالية في اختيار طريقة العينة العشوائية لتمثيل مجتمع الدراسـة. 
لتحقيق أغراض الدراسـة؛ استخدمت الباحثة المنهج الوصفي التحليلي، كونه أحد أشكال التحليل والتفسير العلمي المنظم لوصف الظاهرة كميًا عن طريق جمع البيانات والمعلومات المقننة عن الظاهرة، وتصنيفها وتحليلها وإخضاعها للدراسة الدقيقة.

مجتمع الدراسة وعينتها: تكون مجتمع الدراسـة من جميع معلمي العلوم ومعلماتها في المرحلة الأساسية العليا في مديريات محافظة الخليل الأربعة (شمال الخليل، وسط الخليل، جنوب الخليل، يطا)، وقد قامت الباحثة بتطبيق أداة الدراسة

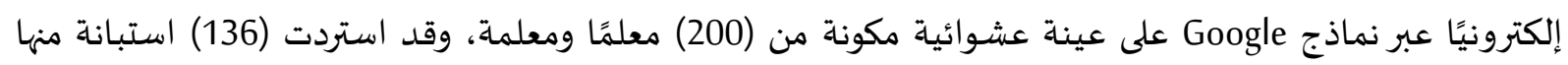

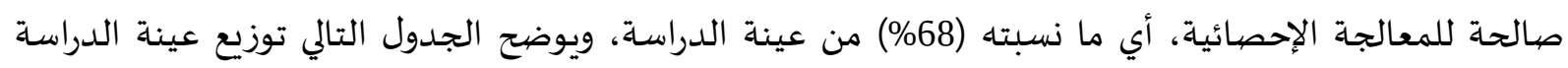
حسب متغيري الجنس والمديرية. جدول (1) توزيع عينة الدراسة والنسب المئوية حسب متغيري الجنس والمديرية

\begin{tabular}{|c|c|c|c|c|c|c|c|}
\hline \multirow{2}{*}{ المئوية } & \multirow[b]{2}{*}{ المجموع } & \multicolumn{4}{|c|}{ الملديرية } & \multirow{2}{*}{ المستوى / الفئة } & \multirow[b]{2}{*}{ المتغير } \\
\hline & & يطا & جنوب الخليل & وسط الخليل & شمال الخليل & & \\
\hline $45.59 \%$ & 62 & 19 & 17 & 14 & 12 & ذكر & \multirow{2}{*}{ الجنس } \\
\hline $54.41 \%$ & 74 & 14 & 27 & 20 & 13 & أنثى & \\
\hline $100 \%$ & 136 & 33 & 44 & 34 & 25 & \multicolumn{2}{|c|}{ المجموع } \\
\hline & $100 \%$ & $24.26 \%$ & $32.35 \%$ & $25 \%$ & $18.38 \%$ & \multicolumn{2}{|c|}{ النسبة المئوية } \\
\hline
\end{tabular}

أداة الدراسة:

من أجل تحقيق هدف الدراسة المتمثل في بيان العلاقة بين استخدام معلمي العلوم لاستراتيجية الصف

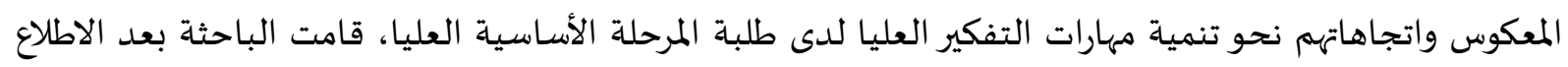

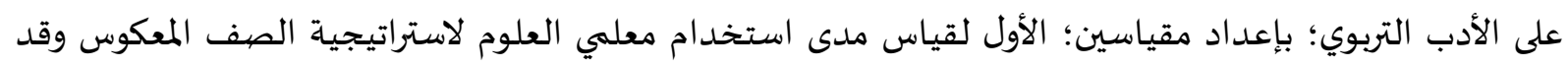

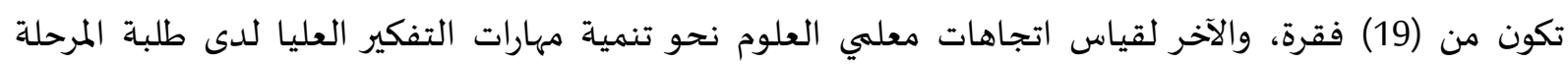

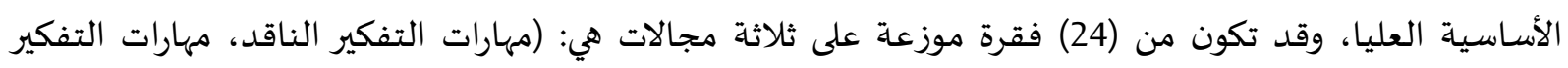

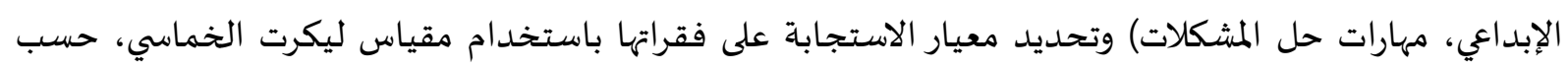

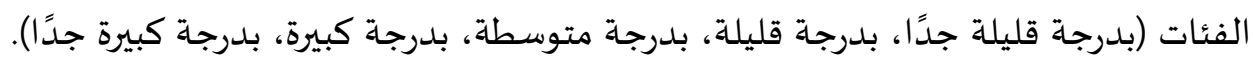

صدة الأداة:

الصددق الظاهري (المحكمين):

قامت الباحثة بعرض النسخة الأولية من أداة الدراسة على مجموعة من المحكمين ذوي الاختصاص، للاطلاع عليها وإبداء أراءهم فيها من حيث ملاءمة كل فقرة من فقرات الاستبانة لقياس الهدف المراد منها، بالإضافة 


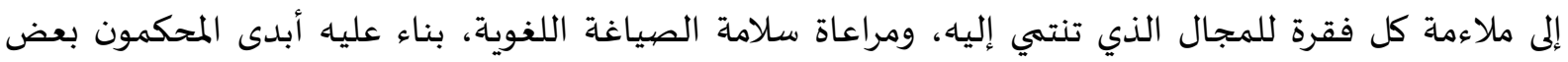
الملاحظات الطفيفة حول أداة الدراسة، حيث قامت الباحثة بإجراء التعديلات اللازمة واستخراج الأداة بصورتهاء لئهاء

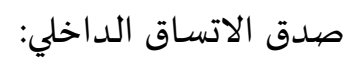

حيث قامت الباحثة بحساب معامل الارتباط بيرسون بين فقرات الاستبانة والدرجة الكلية، وتراوحت

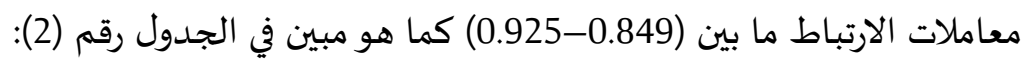

\begin{tabular}{|c|c|c|c|c|}
\hline الارتباط & 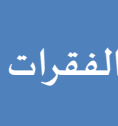 & \multicolumn{2}{|c|}{ المحور } & \# \\
\hline $.913^{* *}$ & 19 & \multicolumn{2}{|c|}{ المحور الأول: مدى استخدام معلمي العلوم لاستراتيجية الصف المعكوس } & 1 \\
\hline $.880^{* *}$ & 8 & مهارات التفكير الناقد الت & \multirow{4}{*}{ العلوم نحور الثاني: اتجاهات معلمية مهارات التفكير } & \\
\hline $.888^{* *}$ & 8 & 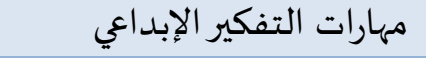 & & 7 \\
\hline $.849^{* *}$ & 8 & 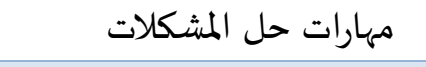 & & \\
\hline \multirow[t]{2}{*}{$.925^{* *}$} & 24 & إجمالي المحور الثاني إن & & \\
\hline & 43 & \multicolumn{2}{|c|}{ 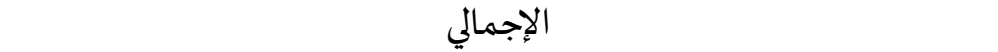 } & \\
\hline
\end{tabular}

جدول (2): معامل ارتباط المحاور بالدرجة الكلية للاستبانة المدول

ثبات الأداة:

حيث استخدمت الباحثة معامل ألفا كرونباخ (Cronbach's Alpha coefficient) في حساب معامل الثبات

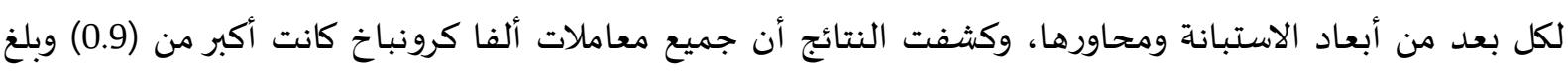

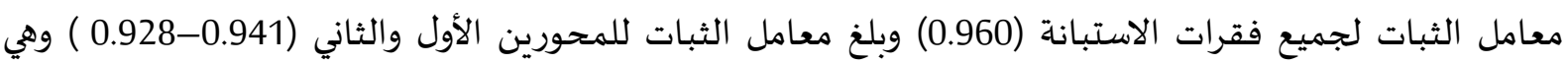

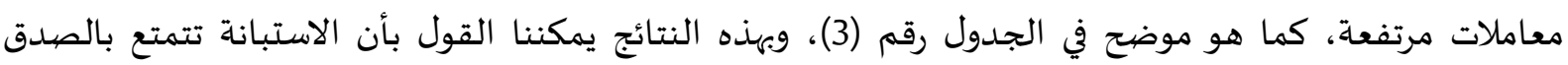
والثبات وهي صالحة للتطبيق على عينة الدراسة الفعلية.

\begin{tabular}{|c|c|c|c|c|c|}
\hline \multicolumn{2}{|c|}{ التجزئة النصيفية } & \multirow{2}{*}{ كرون ألفا } & \multirow[b]{2}{*}{ الفقرات } & \multirow[b]{2}{*}{ 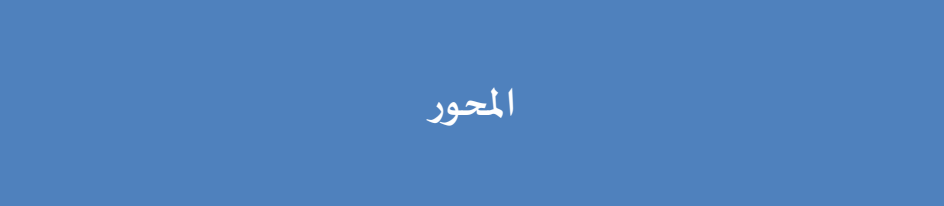 } & \\
\hline معامل الثبات & الاختبار & & & & \# \\
\hline 0.925 & جتمان & 0.941 & 19 & مدى استخدام معلمي العلوم لاستراتيجية الصف المعكوس & 1 \\
\hline 0.909 & 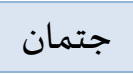 & 0.928 & 24 & اتجاهات معلمي العلوم نحو تنمية مهارات التفكير العليا لدى الطلبة & 2 \\
\hline 0.884 & جتمان & 0.960 & 43 & 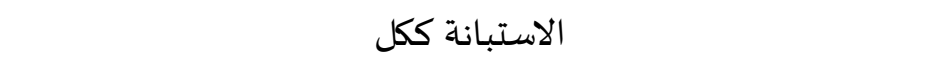 & \\
\hline
\end{tabular}

جدول (3): معامل ألفا كرونباخ والتجزئة النصيفية النية 
النتائج المتعلقة بالإجابة عن السؤال الأول: ما مدى استخدام معلمي العلوم لاستراتيجية الصف المعكوس

في تدريس طلبة المرحلة الأساسية العليا في محافظة الخليل؟ بألمأ

ولإججابة على هذا السؤال قامت الباحثة بحساب المتوسطات الحسابية والانحرافات المعيارية ومستوى

الاتجاه للمحور الأول للاستبانة " مدى استخدام معلمي العلوم لاستراتيجية الصف المعكوس"، والجدول (4) يوضح

جدول (4): المتوسطات الحسابية والانحراف المعياري لفقرات محور استخدام استراتيجية الصف المعكوس

\begin{tabular}{|c|c|c|c|c|c|c|}
\hline 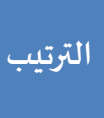 & 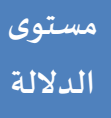 & 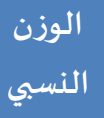 & 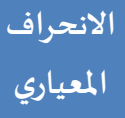 & المتوسط الحسبي & 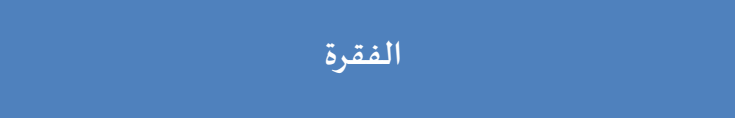 & $\#$ \\
\hline 19 & مرتفع & 76.3 & .72216 & 3.8162 & يتناسب نمطي في التدريس مع استراتيجية الصف المعكوس. & 1 \\
\hline 7 & مرتفع & 81.9 & .66532 & 4.0956 & أبذل قصهارى جهدي لإدماج الأنشطة الصفية والتقنيات & 2 \\
\hline 5 & مرتفع & 82.6 & .72836 & 4.1324 & تساعدني استراتيجية الصف المعكوس على تحقيق أهداف & 3 \\
\hline 6 & 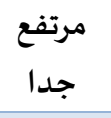 & 82.3 & .77037 & 4.1176 & تساعدني استراتيجية الصف المعكوس على تحقيق العدالة & 4 \\
\hline 9 & مرتفع & 80.4 & .77428 & 4.0221 & توظيف استراتيجية الصف المعكوس يسهم في تطوير & 5 \\
\hline 10 & مرتفع & 78.8 & .78660 & 3.9412 & استخدام استراتيجية الصف المعكوس يساعد على عرض منظم. & 6 \\
\hline 13 & مرتفع & 77.6 & .84379 & 3.8824 & يزودني استخدام استراتيجية الصف المعكوس بتغذية & 7 \\
\hline 1 & مرتفع & 85.1 & .66663 & 4.2574 & استخدام استراتيجية الصفف المعكوس يزيد من دافعية & 8 \\
\hline 12 & مرتفع & 78.2 & .72491 & 3.9118 & استخدام استراتيجية الصفف المعكوس ينمي مقدرة & 9 \\
\hline 8 & 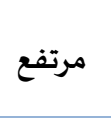 & 81.3 & .76208 & 4.0662 & يساعد استخدام استراتيجية الصف المعكوس على تطوير & 10 \\
\hline 17 & 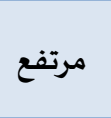 & 76.9 & .81540 & 3.8456 & تساعد استراتيجية الصفف المعكوس على مراعاة الفروق & 11 \\
\hline 14 & 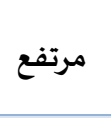 & 77.3 & 69718 & 3.8676 & استخدام استراتيجية الصف المعكوس يساعد المتعلمين & 12 \\
\hline 2 & 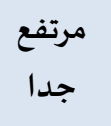 & 83.8 & .80291 & 4.1912 & استخدام استراتيجية الصف المعكوس يزيد من درجة & 13 \\
\hline 11 & مرتفع & 78.8 & .90074 & 3.9412 & استخدام استراتيجية الصفف المعكوس يوفر للمتعلم & 14 \\
\hline
\end{tabular}


المجلة العربية للطوم ونشر الأبحاث ـ مجلة العلوم التريوية والنفسية ـ المجلد الخامس ـ العدد التاسع والثلاثون ـ أكتوبر 2021م

\begin{tabular}{|c|c|c|c|c|c|c|}
\hline الترتيب & 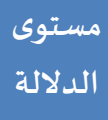 & النسبي & الانحراف & المتوسط الحسبابي & الفقرة & $\#$ \\
\hline 3 & 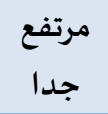 & 83.6 & .76208 & 4.1838 & استخدام استراتيجية الصف المعكوس يسهم في تقبل & 15 \\
\hline 15 & مرتفع & 77.3 & .92543 & 3.8676 & استخدام استراتيجية الصف المعكوس يسـاعد على توفير & 16 \\
\hline 4 & جرتفع & 82.7 & .75201 & 4.1397 & استخدام استراتيجية الصف المعكوس يشجع المتعلمين & 17 \\
\hline 18 & 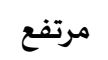 & 76.6 & .70506 & 3.8309 & تنمي استراتيجية الصيف المعكوس ثقة المتعلم بنفسـه. & 18 \\
\hline \multirow[t]{2}{*}{16} & 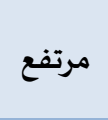 & 77.0 & .85660 & 3.8529 & تساعد استراتيجية الصفف المعكوس المتعلمين ذوي & 19 \\
\hline & 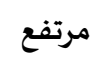 & 79.9 & .53904 & 3.9981 & 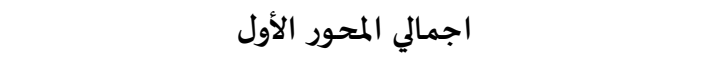 & \\
\hline
\end{tabular}

تشير نتائج الجدول (4) أن جميع متوسطات فقرات المحور الثاني "مدى استخدام معلمي العلوم

لاستراتيجية الصف المعكوس" جاءت بدرجة استخدام مرتفعة، حيث بلغ المتوسط حسابي للمحور ككل (3.99)

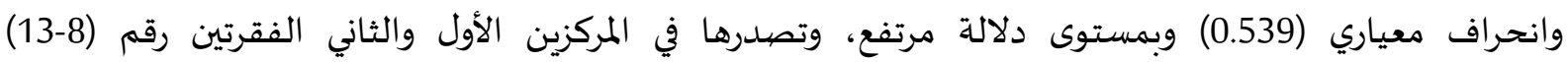

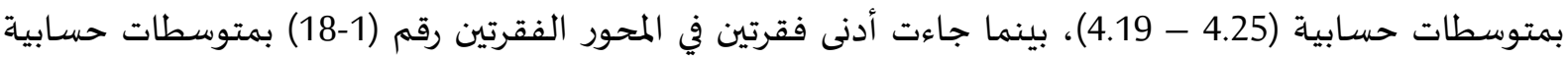

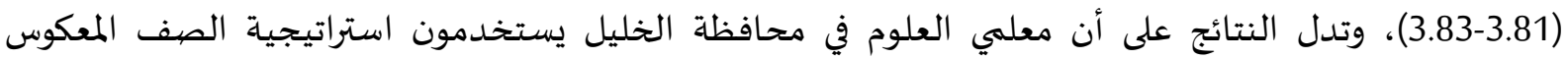

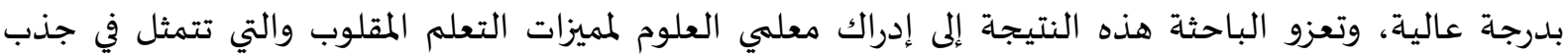

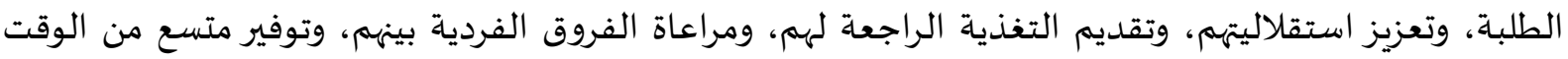

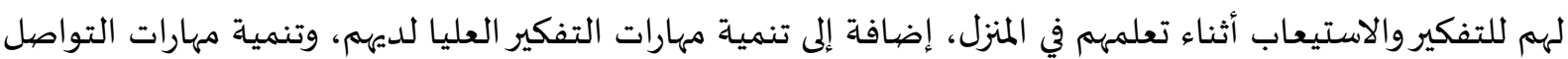

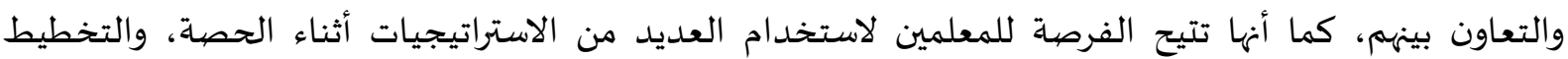
والإعداد المناسب للدرس. وتتفق هذه النتيجة مع دراسة (العنزي، 2020) التي بينت أن معلمي المرحلة المتوسطة في المئراتيات مدينة عرعر بالسعودية يطبقون استراتيجية الصف المقلوب بدرجة كبيرة، فيما تختلف مع نتيجة دراسة دراسة (المجالي،

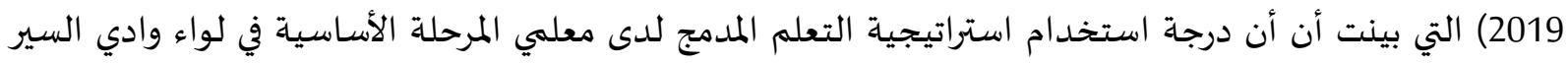

جاءت بدرجة متوسطة.

النتائج المتعلقة بالإجابة عن السؤال الثاني للدراسة: ما اتجاهات معلمي العلوم نحو تنمية مهارات التفكير

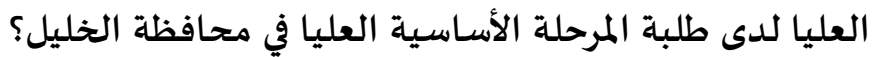

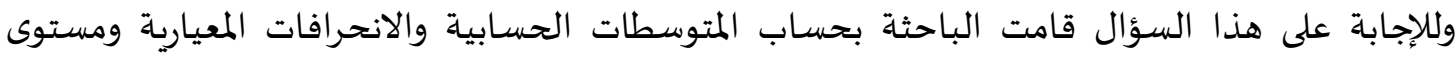
الاتجاه للمحور الثاني للاستبانة "اتجاهات معلمي العلوم نحو تنمية مهارات التفكير العليا لدى الطلبة"، والجدول (5) جدول (5): المتوسطات الحسابية والانحراف المعياري لفقرات محور مهارات التفكير العليا يوضح النتائج:

\begin{tabular}{|c|c|c|c|c|c|c|}
\hline الترتيب & دورجة & النسبي & المعياري & المتوسطابي & 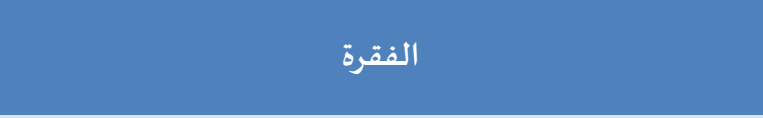 & $\#$ \\
\hline 5 & كبيرة & 77.05 & 65012 & 3.8529 & أقوم ببناء تفسيرات وتمارين للتفكير النقدي في معظم دروسي. & 1 \\
\hline 4 & كبيرة & 78.38 & 66728 & 3.9191 & أشجع الطلبة على استنتاج النتائج من الحقائق والبيانات. & 2 \\
\hline
\end{tabular}


المجلة العربية للطوم ونشر الأبحاث ـ مجلة العلوم التريوية والنفسية ـ المجلد الخامس ـ العدد التاسع والثلاثون ـ أكتوبر 2021م

\begin{tabular}{|c|c|c|c|c|c|c|}
\hline الترتيب & 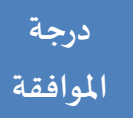 & 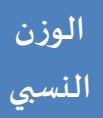 & المعياري - المراف & المتوسط المسابي & 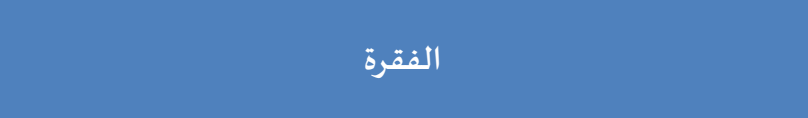 & $\#$ \\
\hline 2 & كبيرة & 81.32 & .78128 & 4.0662 & 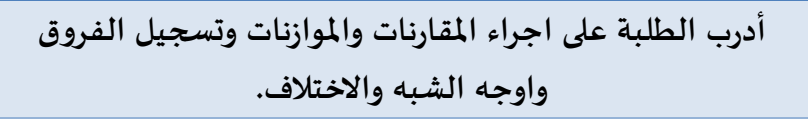 & 3 \\
\hline 3 & كبيرة & 80.14 & .72517 & 4.0074 & أعزز قدرة الطلبة على تمييز المعلومات غير المرتبطة بالموضوع. & 4 \\
\hline 6 & كبيرة & 76.17 & .79363 & 3.8088 & 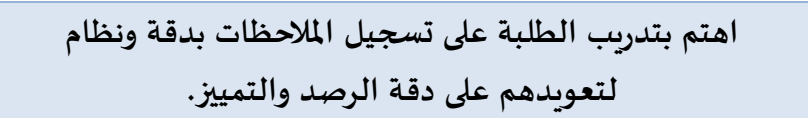 & 5 \\
\hline 7 & كبيرة & 75 & .71751 & 3.7500 & أدرب الطلبة على التلخيص والنقد. & 6 \\
\hline 1 & جبدًا & 82.20 & .73709 & 4.1103 & أشجع الطلبة على التخيل ووضيع الافتراضيات. & 7 \\
\hline 8 & كبيرة & 73.97 & .99122 & 3.6985 & أدرب الطلبة على جمع المعلومات حول موضيوع ما وتنظيم الأفكار & 8 \\
\hline & كبيرة & 78.03 & .53151 & 3.9017 & إجمالي: مهارة التفكير الناقد إلد & \\
\hline 2 & كبيرة & 79.11 & .83327 & 3.9559 & أشجع الطلبة على التعبير عن أفكارهم. & 1 \\
\hline 1 & كبرًا & 84.26 & .74444 & 4.2132 & أهتم بأفكار الطلبة وأصني لها. & 2 \\
\hline 7 & متوسطة & 62.05 & 1.3011 & 3.1029 & أعزز روح المثابرة والتنافس الإيجابي بين الطلبة. & 3 \\
\hline 8 & 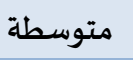 & 61.76 & 1.2965 & 3.0882 & استثير انتباه الطلبة بأفكار متنوعة. & 4 \\
\hline 5 & كبيرة & 74.26 & .94209 & 3.7132 & أشجع الطلبة على التفكير بشكل مستقل عن الآخرين. & 5 \\
\hline 6 & كبيرة & 72.35 & .81703 & 3.6176 & أشجع الطلبة على استنباط معلومات وأفكار جديدة من تلك التي & 6 \\
\hline 3 & كبيرة & 78.97 & .63619 & 3.9485 & أشجع الطلبة على إثارة نقاش حول مواضيع محددة. & 7 \\
\hline 4 & كبيرة & 78.23 & .79322 & 3.9118 & أركز على اظهار قدرات الطلبة الإبداعية من خلال تكليفهم ببعض الأنشط. & 8 \\
\hline & كبيرة & 73.87 & .70806 & 3.6939 & إجمالي: مهارات التفكير الإبداعي & \\
\hline 4 & كبيرة & 78.97 & .75346 & 3.9485 & أقوم بإعداد المادة التعليمية على صهورة مواقف أو مشكلات. & 1 \\
\hline 3 & كبيرة & 80.58 & .90219 & 4.0294 & أدرب الطلبة على الشعور بالمشكلة وتحديد الاطار المعرفي لها. & 2 \\
\hline 2 & جبدًا & 82.20 & .89171 & 4.1103 & أدرب الطلبة على التعرف على أسباب حدوث المشكلة وحلولها. & 3 \\
\hline 5 & كبيرة & 77.05 & .78438 & 3.8529 & أزود الطلبة بالمواد التي تسهل صياغة البدائل. & 4 \\
\hline 1 & جبرًا & 82.94 & .73565 & 4.1471 & أشارك البدائل التي يتوصل الهيا مجموعات الطلبة مع المجمعات & 5 \\
\hline 7 & 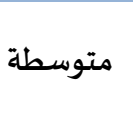 & 63.08 & 1.1730 & 3.1544 & أسجل البدائل على السبورة أو أجهزة العرض وأناقشها مع الطبلة & 6 \\
\hline 8 & 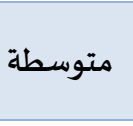 & 61.32 & 1.1687 & 3.0662 & أدرب الطلبة في مواقف مختلفة لصياغة بدائل وحلول لمشكلات & 7 \\
\hline \multirow[t]{3}{*}{6} & كبيرة & 72.94 & .83026 & 3.6471 & أدرب الطلبة على استيعاب معايير البديل الأمثل وصياغته. & 8 \\
\hline & 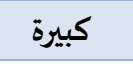 & 74.88 & .53681 & 3.7445 & إجمالي: مهارات حل المشكلات & \\
\hline & كبيرة & 75.60 & .54167 & 3.7800 & 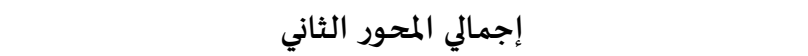 & \\
\hline
\end{tabular}


تشير نتائج الجدول (5) أن المتوسط الحسابي الإجمالية للمحور الثاني للدراسة "اتجاهات معلمي العلوم نحو

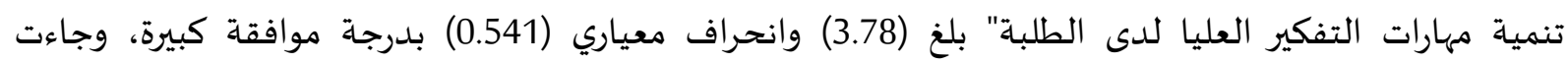

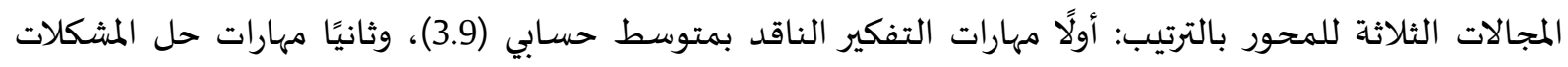

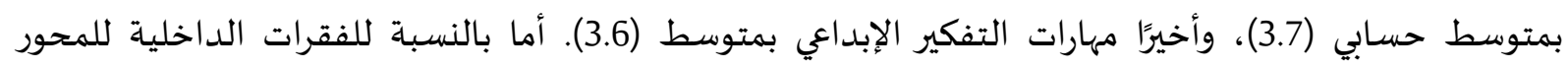

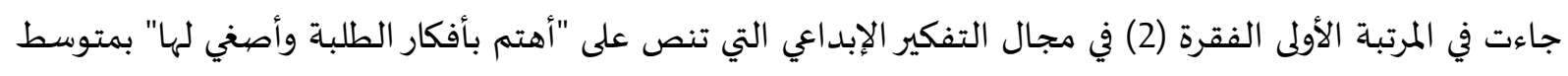

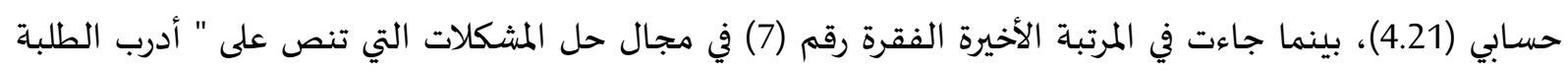

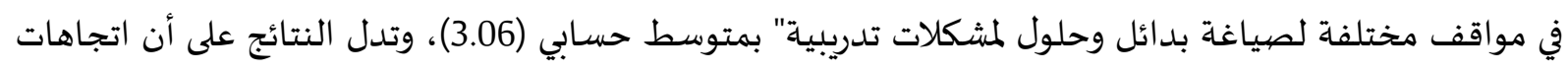

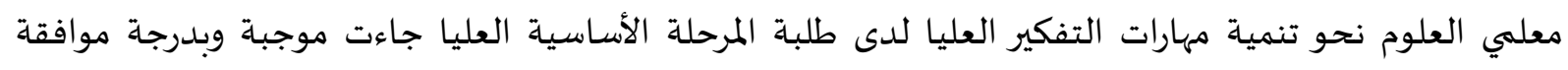
كبيرة، وتعزو الباحثة هذه النتيجة إلى إدراك معلمي العلوم في المرحلة الأساسية العليا لأهمية مهارات التفكير العليا

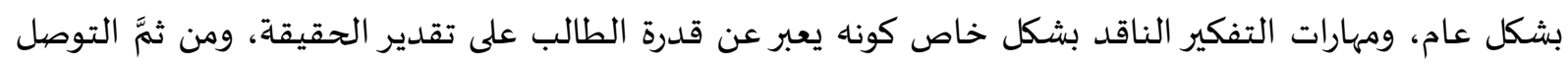

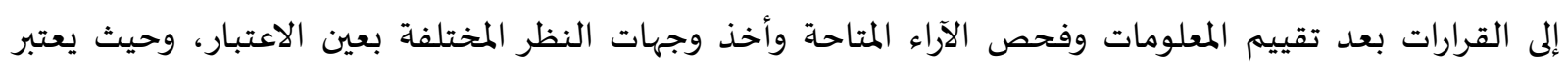

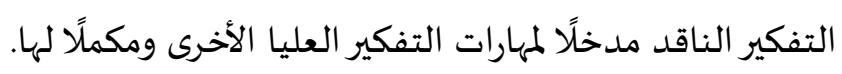

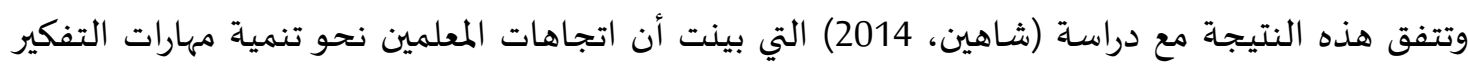

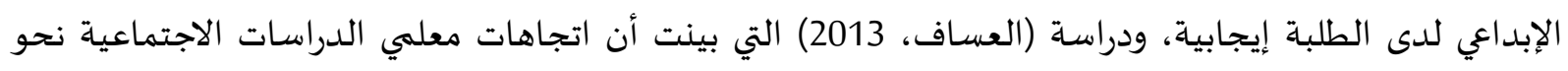

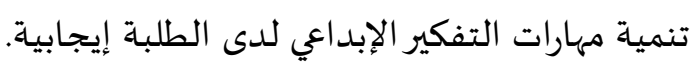

النتائج المتعلقة بالإجابة عن السؤال الثالث للدراسة: هل توجد علاقة دالة إحصائيًا بين استخدام معلمي

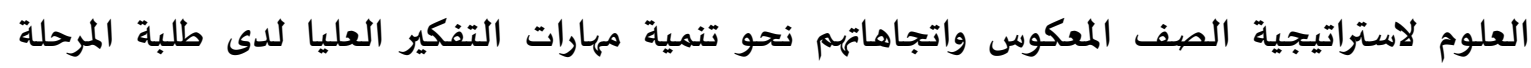

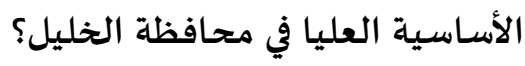
وللإجابة على هذا السؤال قامت الباحثة بحساب معامل الارتباط بيرسون بين المتوسطات الحسابية لمحاور الاستبانة مع المتوسط الحسابي للاستبانة ككل، والجدول (6) يوضح النئة النتائج: جدول (6): معامل الارتباط بيرسون Pearson Correlation بين محاور الاستبانة

\begin{tabular}{|c|c|c|c|c|c|c|c|c|}
\hline \multirow[b]{2}{*}{ الدلالة } & \multirow{2}{*}{$\begin{array}{c}\text { Sig } \\
(2- \\
\text { tailed })\end{array}$} & \multicolumn{3}{|c|}{ الارتباط بيرسون } & \multirow[b]{2}{*}{ العدد } & \multirow[b]{2}{*}{ المستوسط المسي } & \multirow[b]{2}{*}{ المحاور } & \\
\hline & & الإجمالي & المحتور & المحور - المول & & & & \\
\hline \multirow{3}{*}{ جميعها } & .000 & $.927^{* *}$ & $.774^{* *}$ & 1 & 19 & 3.9981 & لاستراتيجية استخدام معلمي العلوم المعكوس & 1 \\
\hline & .000 & $.955^{* *}$ & 1 & $.774^{* *}$ & 24 & 3.7800 & اتجاهات معات التفكير العليا لدى العلوم نحو تنمية & 2 \\
\hline & .000 & 1 & $.955^{* *}$ & $.927^{* *}$ & 43 & 3.8764 & الإجمالي & 3 \\
\hline
\end{tabular}

ويشير الجدول (6) أن معامل الارتباط بين المحور الأول " مدى استخدام معلمي العلوم لاستراتيجية الصف الماتف

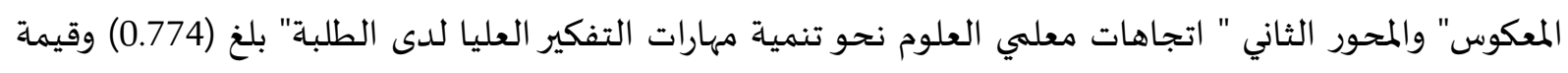

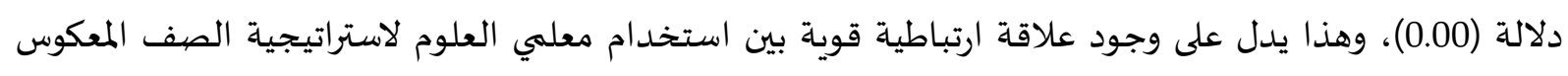

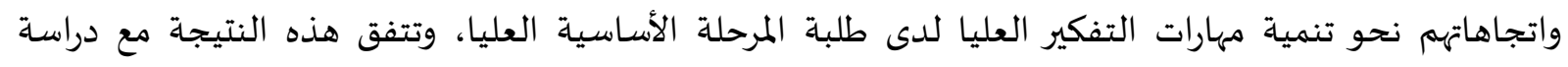


(عباس، 2020) التي أظهرت وجود علاقة ارتباطية طردية دالة إحصائيًا بين اتجاهات أعضاء هيئة التدريس نحو التدريس بنموذج الصف المقلوب وبين احتياجاتهم التدريبية اللازمة لاستخدامهاه.

النتائج المتعلقة بالإجابة عن السؤال الرابع: "هل توجد فروق دالة إحصائيًا في استخدام معلمي العلوم لاستراتيجية الصف المعكوس في تدريس طلبة المرحلة الأساسية العليا في محافظة الخليل تعزى إلى متغيري المديرية والنوع؟

قامت الباحثة بتقسيم السؤال إلى قسمين تبعًا لمتغيري الدراسة (الجنس والمديرية)، حيث نص السؤال

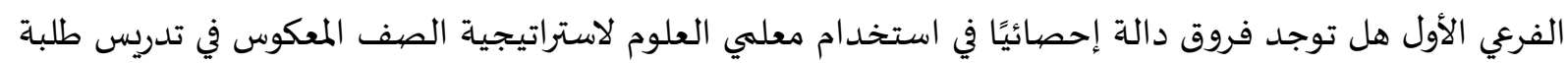

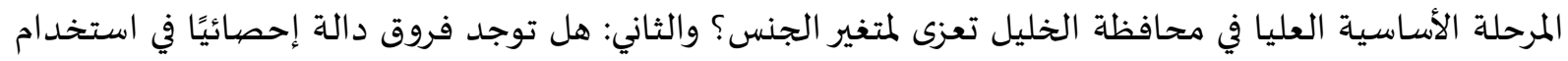

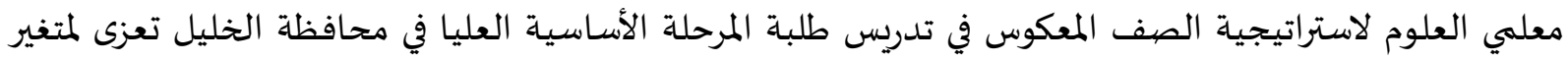

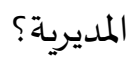
للإجابة عن السؤال الفرعي الأول قامت الباحثة بحساب المتوسطات الحسابية للمحور الأول حسب متغير

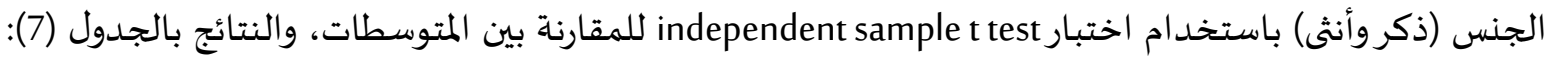

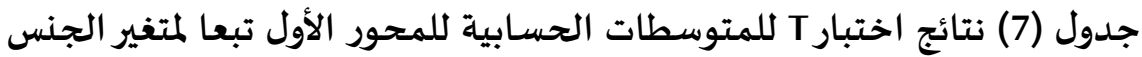

\begin{tabular}{|c|c|c|c|c|c|c|c|}
\hline مستوى الدلالة & قيمة الدلالة & قيمة ت & الانحراف & المتوسط & العدد & فئات & المتغير \\
\hline \multirow{3}{*}{ دالة احصائيا } & \multirow{3}{*}{.012} & \multirow{3}{*}{2.533} & .55835 & 3.8727 & 62 & ذكر & \multirow{3}{*}{ الجنس } \\
\hline & & & .50230 & 4.1031 & 74 & أنثى & \\
\hline & & & & & 136 & المجموع & \\
\hline
\end{tabular}

يتضح من الجدول (7) أن متوسطات أفراد عينة الدراسة حسب متغير الجنس (ذكر، أنثى)، حيث بلغ عدد

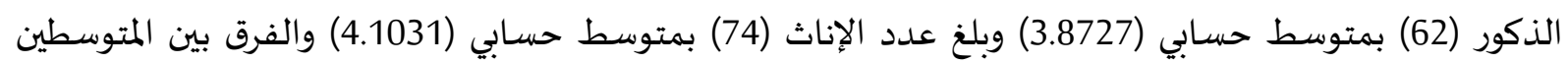

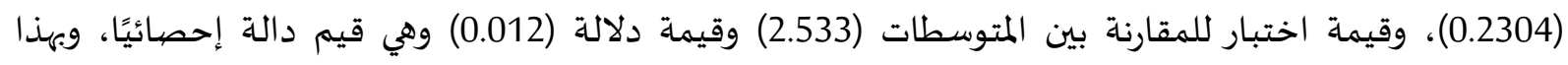

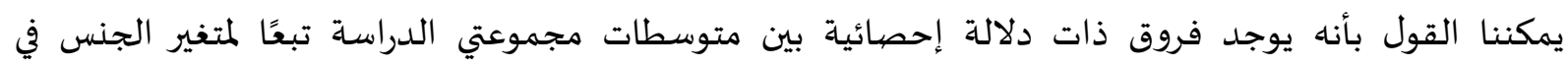

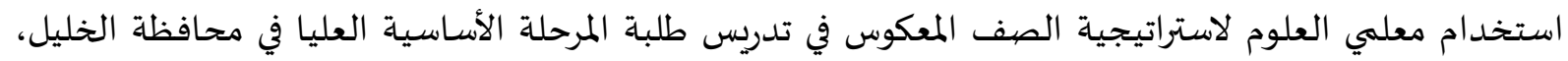

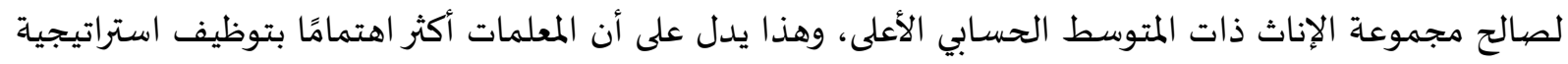

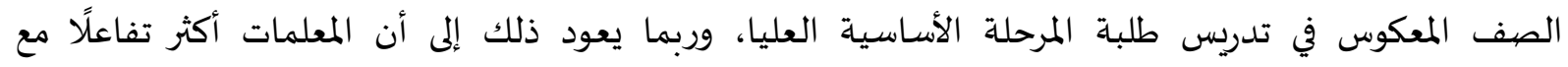
المستجدات، وأكثر اهتمامًا بالتخطيط وإعداد الدروس بما يجذب انتباه الطلبة، ومراعاة الفروق الفردية بينهم، مقارنة بالمعلمين. وتتفق هذه النتيجة مع دراسة (المجالي، 2019) التي أظهرت وجود فروق ذات دلالة إحصائية تبعًا لمتغير

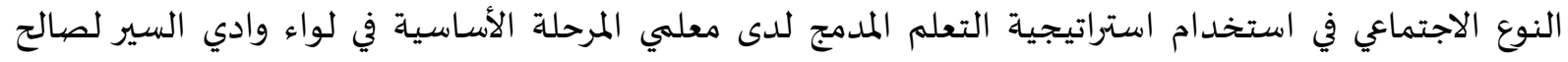
الإناث.

ولإجابة عن السؤال الفرعي الثاني قامت الباحثة بتحليل فقرات المحور الأول باستخدام اختبار تحليل

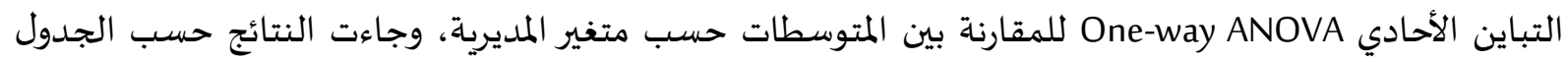


جدول (8): نتائج اختبار ANOVA للمقارنة بين متوسطات المحور الأول تبعا لمتفير المديرية

\begin{tabular}{|c|c|c|c|c|c|c|c|}
\hline مستوى الدلالة & قيمة Sig & فيمة & متوسط المربعات & الحرية & المربعات & المصدر & المحور \\
\hline \multirow{3}{*}{ إحصائيا } & \multirow{3}{*}{.005} & \multirow{3}{*}{4.475} & 1.207 & 3 & 3.622 & بين المجموعات & \multirow{3}{*}{ المأول } \\
\hline & & & .270 & 132 & 35.605 & المجموعات داخل & \\
\hline & & & & 135 & 39.227 & المجموع & \\
\hline
\end{tabular}

يتضح من الجدول (8) للمقارنة متوسطات أفراد عينة الدراسة حسب متغير المديرية أن قيمة ف جاءت

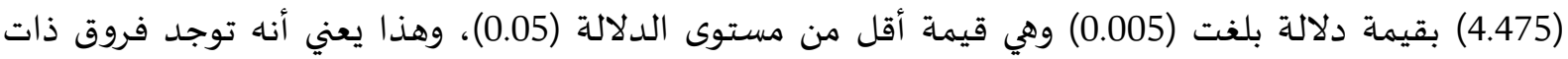

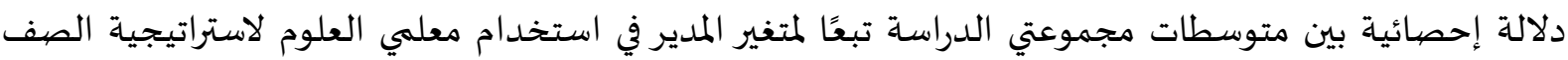

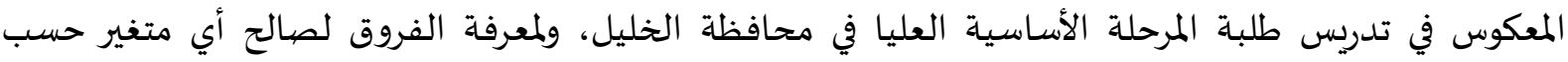

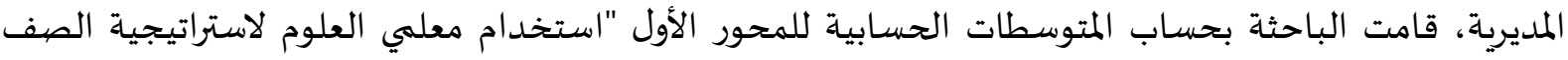

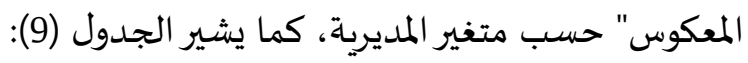

جدول (9): المقارنة بين متوسطات المحور الأول تبعا لمتغير المديرية

\begin{tabular}{|c|c|c|c|}
\hline الانحراف المعياري & المتوسط الحسابي & 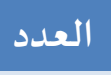 & المتغير \\
\hline .51954 & 4.2758 & 25 & مديرية شمال الخليل \\
\hline .48567 & 3.9675 & 34 & مديرية وسط الخليل \\
\hline .50052 & 4.0299 & 44 & مديرية جنوب الخليل \\
\hline .57475 & 3.7767 & 33 & مديرية يطا \\
\hline .53904 & 3.9981 & 136 & الإجمالي \\
\hline
\end{tabular}

يتضح من الجدول (9) أن الفروق في المتوسطات الحسابية للمحور الأول حسب متغير المديرية لصالح

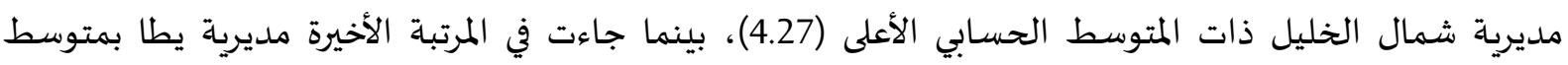

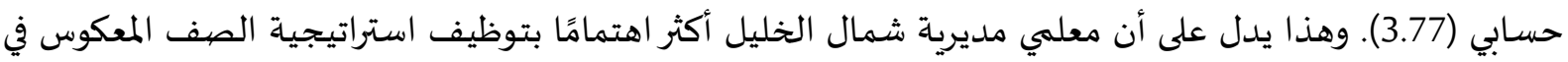
تدريس طلبة المرحلة الأساسية العليا مقارنة بمديريات محافظة الخلي انليل الأخرى.

هالنتائج المتعلقة بالإجابة عن السؤال الخامس: هل توجد فروق دالة إحصائيًا في اتجاهات معلمي العلوم

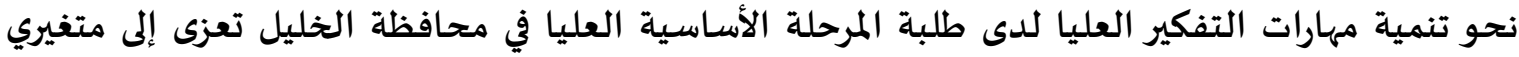
المديرية والنوع؟

قامت الباحثة بتقسيم السؤال إلى قسمين تبعًا لمتغيري الدراسة (الجنس والمديرية)، بحيث ينص السؤال الأول هل توجد فروق دالة إحصائيًا في اتجاهات معلمي العلوم نحو تنمية مهارات التفكير العليا لدى طلبة المبات المرحلة

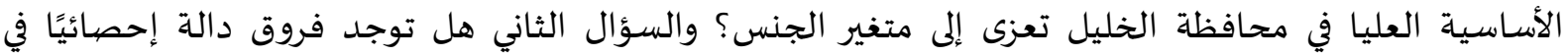

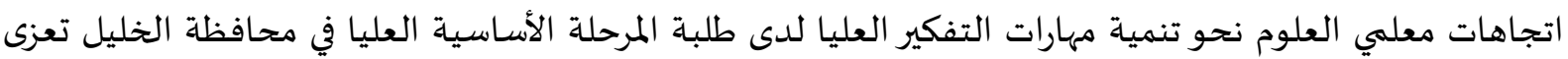
إلى متغير المديرية؟ 
للإجابة عن السؤال الفرعي الأول قامت الباحثة بحساب المتوسطات الحسابية للمحور الثاني حسب متغير

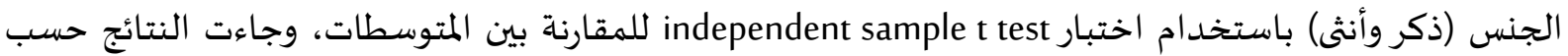

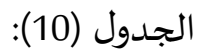

جدول (10): نتائج اختبار T للمتوسطات الحسابية للمحور الثاني تبعا لمتفير الجنس

\begin{tabular}{|c|c|c|c|c|c|c|c|}
\hline مستوى الدلالة & قلديمة & قيمة ت & الانحراف المعياري & المتوسط & العدد & فلمتئتي & المتغير \\
\hline \multirow{3}{*}{ دالة احصائيا } & \multirow{3}{*}{.000} & \multirow{3}{*}{4.049} & .57297 & 3.5853 & 62 & ذكر & \multirow{3}{*}{ الجنس } \\
\hline & & & .45730 & 3.9431 & 74 & أنثى & \\
\hline & & & & & 136 & المجموع & \\
\hline
\end{tabular}

يتضح من الجدول (10) أن متوسطات أفراد عينة الدراسة حسب متغير الجنس (ذكر، أنثى)، حيث بلغ

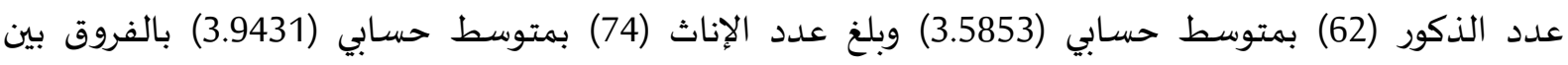
المتوسطين (0.3578)، وقيمة اختبار للمقارنة بين المتوسطات (4.049) وقيمة دلالة (0.000) وهي قيم دالة إحصائيًا،

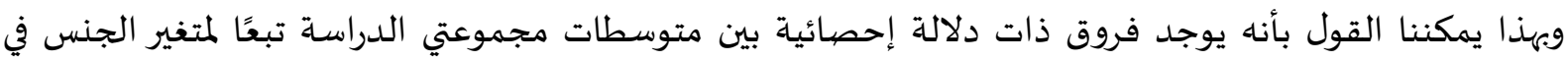

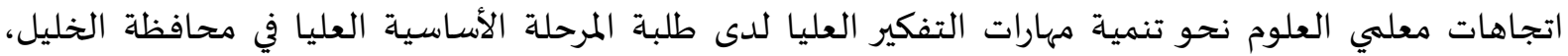

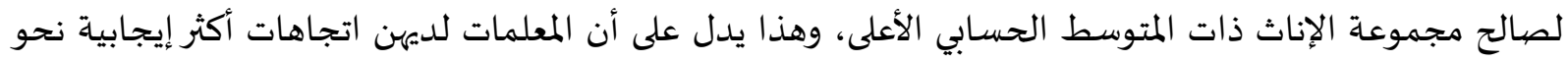
تنمية مهارات التفكير العليا لدى طلبة المرحلة الأساسية العليا مقارنة بالمعلمين، وربما يعود ذلك إلى إدراك المعلمات

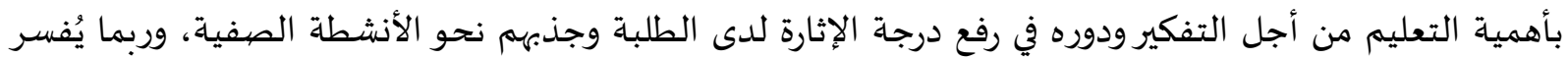
ذلك بمشاعر الأمومة التي تظهرها المعلمات تجاه طلاهن، حيث الاهتمام بتنمية بعض المهارات الحياتية الأساسية وغير الأساسية لديهم.

وللإجابة عن السؤال الفرعي الثاني قامت الباحثة بتحليل فقرات المحور الثاني باستخدام اختبار تحليل التباين الأحادي One-way ANOVA للمقارنة بين المتوسطات حسب متغير المديرية، وجاءت النتائج حسب الجدول

جدول (11): نتائج اختبار ANOVA للمقارنة بين متوسطات المحور الثاني تبعا لمتغير المديرية

\begin{tabular}{|c|c|c|c|c|c|c|c|}
\hline مستوى الدلالة & قيمة Sig & قيمة ف & المربعات & الحرية & المربعات & المصلدر & المحور \\
\hline \multirow{3}{*}{ إحصائيا } & \multirow{3}{*}{.014} & \multirow{3}{*}{3.646} & 1.010 & 3 & 3.031 & بين المجموعات & \multirow{3}{*}{ المحاني } \\
\hline & & & .277 & 132 & 36.579 & داخل المجموعات & \\
\hline & & & & 135 & 39.610 & المجموع & \\
\hline
\end{tabular}

يتضح من الجدول (11) للمقارنة بين متوسطات أفراد عينة الدراسة حسب متغير المديرية أن قيمة ف جاءت (3.646) بقيمة دلالة بلغت (0.014) وهي قيمة أقل من مستوى الدلالة (0.05)، وهذا يعني أنه توجد فروق ذات دلالة إحصائية بين متوسطات مجموعتي الدراسة تبعًا لمتغير المديرية في اتجاهات معلمي العلوم نحو تنمية مهارات التفكير العليا لدى طلبة المرحلة الأساسية العليا في محافظة الخليل، ولمعرفة الفروق لصالح أي متغير حسب المديرية، قامت الباحثة بحساب المتوسطات الحسابية للمحور الأول "اتجاهات معلمي العلوم نحو تنمية مهارات التفكير العليا" حسب متغير المديرياة، كما يشير الجدول (12): 
جدول (12): المقارنة بين متوسطات المحور الثاني تبعا لمتغير المديرية

\begin{tabular}{|c|c|c|c|}
\hline الانحراف المعياري & المتوسط الحسابي & 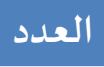 & المتغير \\
\hline .50303 & 4.0000 & 25 & مديرية شـمال الخليل \\
\hline .56977 & 3.7120 & 34 & مديرية وسط الخليل \\
\hline .41656 & 3.8608 & 44 & مديرية جنوب الخليل \\
\hline .62077 & 3.5758 & 33 & مديرية يطا \\
\hline .54167 & 3.7800 & 136 & الإجمالي \\
\hline
\end{tabular}

يتضح من الجدول (12) أن الفروق في المتوسطات الحسابية للمحور الثاني حسب متغير المديرية لصالح

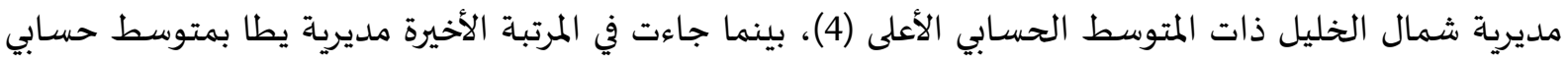
(3.57). وهذا يدل على أن معلمي مديرية شمال الخليل لديهم اتجاهات أكثر إيجابية نحو تنمية مهارات التفكير العليا

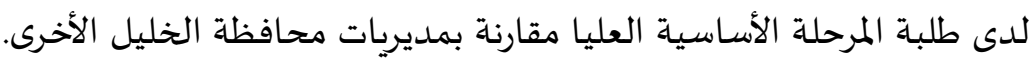

\section{توصيات الدراسـة ومقترحاتها.}

في ضوء النتائج التي توصل إليها البحث، توصي الباحثة وتقترح ما يلي: 1- توفيروسائل الدعم لتشجيع المعلمين على توظيف التقنيات الحديثة في تعليم التفكير. 2- - ضرورة استخدام المعلمين بشكل عام ومعلمين العلوم بشكل خاص لاستراتيجية الصف المعكوس في تدريسهم، وذلك بما يكفل ممارسة الطلاب لمهارات التفكير العليا التي تتضمنها. 3- ضرورة صياغة محتوى العلوم بما يتماشى مع طريقة الصف المعكوس وبما يشجع الطلبة على البحث عن المعلومة، وبما يعزز استخدام استراتيجيات تعلم حديثة.

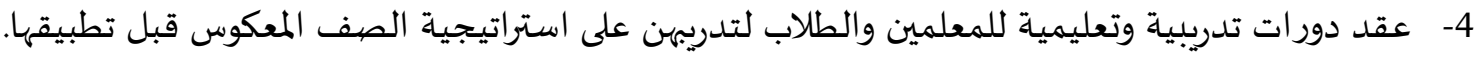
5- إجراء المزيد من الدراسات التي تتناول العلاقة بين اتجاهات المعلمين نحو تنمية مهارات التفكير العليا وتوظيف استراتيجيات تدريسية أخرى. 6- إجراء دراسات تقويمية لفحص مدى فعالية استراتيجيات التعلم المقلوب في تعليم التفكير.

- أبو جلالة، صببحي. (2012). تنمية مهارات التفكير العليا والتفكير الإبداعي. مجلة التربية: اللجنة الوطنية القطرية للتربية والثقافة والعلوم، 41 (181)، 165-194. - آل عامر، حنان. (2010). تعليم التفكير في الرياضيات: أنشطة اثرائية. ديبونو للطباعة والنشروالتوزيع.

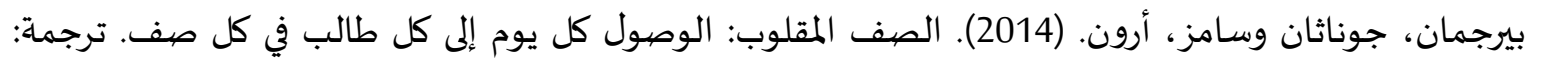

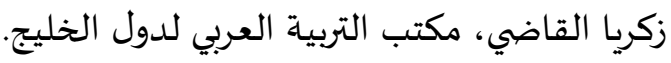
بيرجمان، جوناثان وسامز، أرون. (2015). التعلم المقلوب: بوابة لمشاركة الطلاب. ترجمة: عبد الله الكيلاني، مكتب التربية العربي لدول الخونان وسامز، التون. - م التميهي، أسماء. (2016). مهارات التفكير العليا: الابداعي والناقد. مركز ديبونو لتعليم التفكير. 
جامعة الطائف. (2016). الصف المقلوب. عمادة التعلم الإلكتروني التعليم عن بعد، السعودية. جروان، فتحي. (2003). تعليم التفكير مفاهيم وتطبيقات. ط1، دار الفكر للطباعة والنشر والتوزيع.

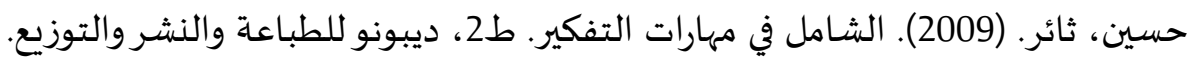

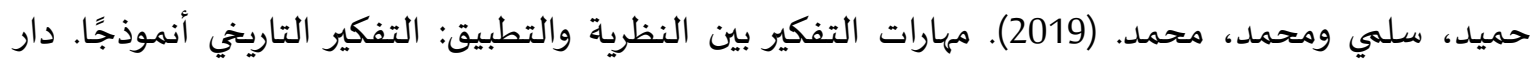
أمجد للنشر والتوزيع. خليل، إبراهيم والتمران، عمر وهاشمي، عبد الحميد (2021). توظيف استراتيجية الصف المقلوب في صفوف

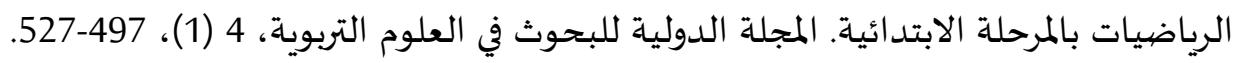
درويش، هاشم. (2015). فاعلية استخدام استراتيجيات شكل البيت الدائري في التحصيل الدراسي والدافعية بتعلم الفيزياء، مجلة دراسات تربوية، (30)، 25-40. زيدان، عفيف والعودة، فداء. (2008). درجة استخدام معلمي المرحلة الأساسية الدنيا لأنماط التفكير الابداعي في تدريس العلوم في محافظة الخليل. مجلة الجامعة الإسلامية للدراسات التربوية والنفسية، 16 (2)، 667-691. السراج، عبد المحسن. (2017). أساليب التفكير وعلاقتها بالسمات السلوكية. دار الكتاب الثقافي. السعدوني، تهاني وفتحي، سعاد، وشلبي، أحمد. (2012). مهارات التفكير الإبداعي لدى طلاب المرحلة الثانوية. دراسات في المناهج وطرق التدريس: جامعاة عين شمس، وفئ، (188)، 15-35.

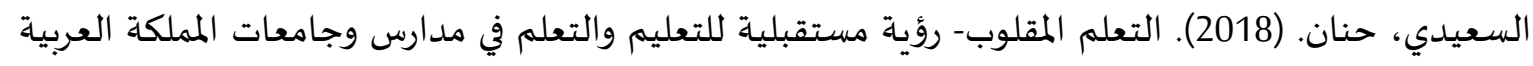

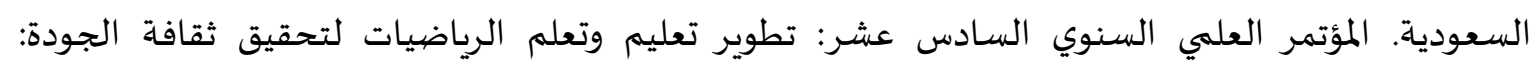
الجمعية المصرية لتربويات الرياضيات، القاهرة، 187- 203.

سلامة، عبد الله. (2021). توظيف التفكير في العملية التعليمية. دار الكتب العلمية. دار الكتب العلمية.

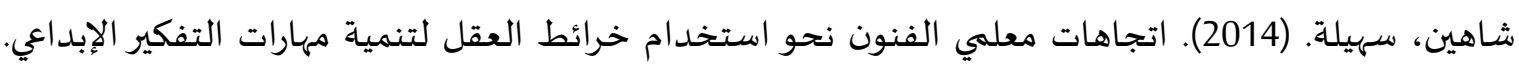

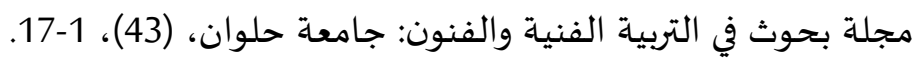

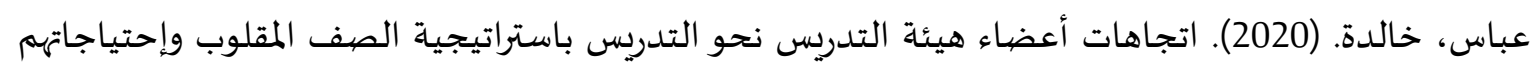
التدرببية اللازمة لاستخدامه. مجلة كلية التربية: جامعة كفر الشيخ، 20 (2)، 179-2024. عبد العزيز، عمرو. (2016). استراتيجية البنتاجرام لتنمية مهارات التفكير وحل المشكلات. مكتبة الانجلو المصرية. العساف، جمال. (2013). اتجاهات معلمي الدراسات الاجتماعية نحو تنمية مهارات التفكير الإبداعي لدى طلبة

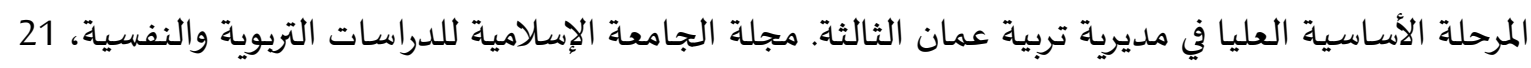
292-269، (1) عسيري، أماني. (2015). توظيف معلمات رياض الأطفال: ركن البحث والاكتشاف في تنمية مهارات التفكير

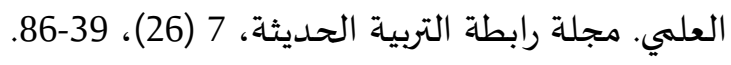

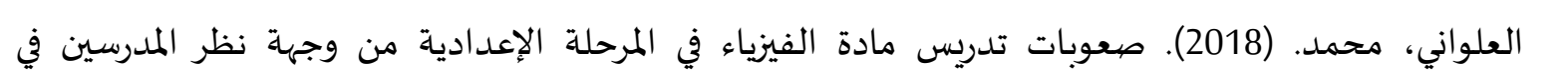
محافظة الانبار /العراق، (رسالة ماجستير غير منشورة)، جامعة الشرق الأوسط، الأردن.

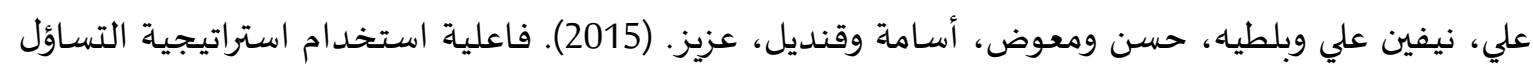

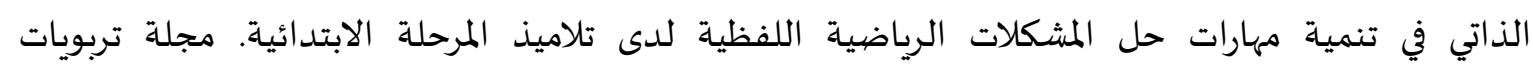

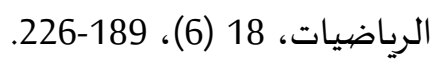


- العنزي، عبد العزيز. (2020). واقع تطبيق معلمي المرحلة المتوسطة في مدينة عرعر بالسعودية لاستراتيجية

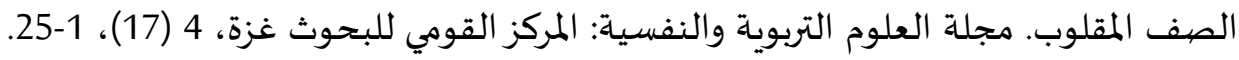

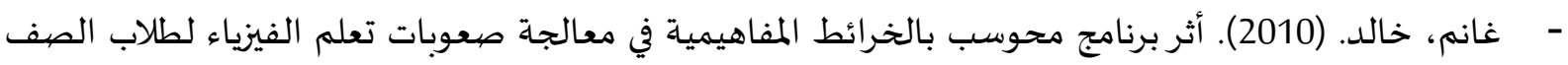
الحادي عشر، (رسالة ماجستير غير منشورة)، الجامعة الاسلامياة، فلسطين.

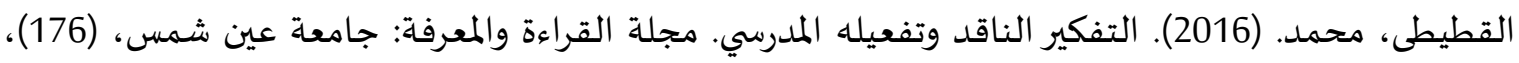
.107-97

المالكي، عبد الملك؛ والشهري، عبد الله. (2020). واقع ممارسة معلمي الرياضيات بالمرحلة المتوسطة لاستراتيجيات تدريس مهارات التفكير العليا. العلوم التربوية: جامعة القاهرة، 28 (1)، 175-213.

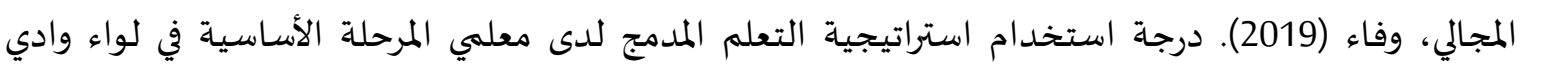
السير. (رسالة ماجستير غير منشورة)، جامعة الشرق الأوسط، الأردن.

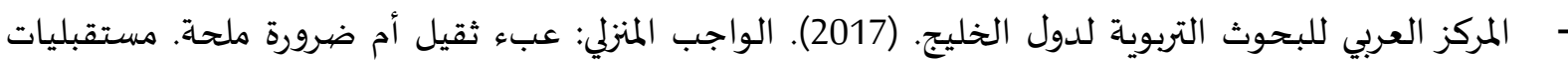
تربوية.

\section{ثانياً - المراجع بالإنجليزية:}

- Abeysekera, L. \& Dawson, P. (2014). Motivation and cognitive load in the flipped classroom: definition, rationale and a call for research. Higher Education Research \& Development. 34. 1-14.

- Bergmann, J., \& Sams, A. (2012). Flip Your Classroom: Reach Every Student in Every Class Every Day (pp. 120-190). Washington DC: International Society for Technology in Education.

- Stone, B. (2012). Flip Your Classroom to Increase Active Learning and Student Engagement. Paper Presented at the Proceedings from 28th Annual Conference on Distance Teaching \& Learning, Madison.

- Verleger, M. \& Bishop, J. (2013). The flipped classroom: A survey of the research. ASEE Annual Conference and Exposition, Conference Proceedings. 